\title{
Dry and wet deposition of inorganic nitrogen compounds to a tropical pasture site (Rondônia, Brazil)
}

\author{
I. Trebs ${ }^{1}$, L. L. Lara ${ }^{2}$, L. M. M. Zeri ${ }^{3}$, L. V. Gatti ${ }^{4}$, P. Artaxo ${ }^{5}$, R. Dlugi ${ }^{6}$, J. Slanina ${ }^{7}$, M. O. Andreae ${ }^{1}$, and \\ F. X. Meixner ${ }^{1}$ \\ ${ }^{1}$ Max Planck Institute for Chemistry, Biogeochemistry Department, P.O. Box 3060, 55020, Mainz, Germany \\ ${ }^{2}$ Centro de Energia Nuclear na Agricultura (CENA), Laboratorio de Ecologia Isotópica, Universidade de São Paulo (USP), \\ Av. Centenario, 303 13400-970, Piracicaba, São Paulo, SP, Brazil \\ ${ }^{3}$ Max Planck Institute for Biogeochemistry, Department Biogeochemical Processes, Hans-Knöll-Straße 10, 07745 Jena, \\ Germany \\ ${ }^{4}$ Instituto de Pesquisas Energéticas e Nucleares, CQMA, Atmospheric Chemistry Laboratory, Av. Prof. Lineu Prestes, 2242, \\ Cidade Universitaria, CEP 055508-900, São Paulo, SP, Brazil \\ ${ }^{5}$ Instituto de Física, Universidade de São Paulo (USP), Rua do Matão, Travessa R, 187, CEP 05508-900, São Paulo, SP, Brazil \\ ${ }^{6}$ Working Group Atmospheric Processes (WAP), Gernotstrasse 11, 80804 Munich, Germany \\ ${ }^{7}$ Peking University, College of Environmental Sciences, Beijing 100871, China
}

Received: 28 February 2005 - Published in Atmos. Chem. Phys. Discuss.: 19 May 2005

Revised: 22 November 2005 - Accepted: 13 December 2005 - Published: 8 February 2006

\begin{abstract}
The input of nitrogen (N) to ecosystems has increased dramatically over the past decades. While total (wet + dry) $\mathrm{N}$ deposition has been extensively determined in temperate regions, only very few data sets of $\mathrm{N}$ wet deposition exist for tropical ecosystems, and moreover, reliable experimental information about $\mathrm{N}$ dry deposition in tropical environments is lacking. In this study we estimate dry and wet deposition of inorganic $\mathrm{N}$ for a remote pasture site in the Amazon Basin based on in-situ measurements. The measurements covered the late dry (biomass burning) season, a transition period and the onset of the wet season (clean conditions) (12 September to 14 November 2002) and were a part of the LBA-SMOCC (Large-Scale Biosphere-Atmosphere Experiment in Amazonia - Smoke, Aerosols, Clouds, Rainfall, and Climate) 2002 campaign. Ammonia $\left(\mathrm{NH}_{3}\right)$, nitric acid $\left(\mathrm{HNO}_{3}\right)$, nitrous acid $(\mathrm{HONO})$, nitrogen dioxide $\left(\mathrm{NO}_{2}\right)$, nitric oxide $(\mathrm{NO})$, ozone $\left(\mathrm{O}_{3}\right)$, aerosol ammonium $\left(\mathrm{NH}_{4}^{+}\right)$ and aerosol nitrate $\left(\mathrm{NO}_{3}^{-}\right)$were measured in real-time, accompanied by simultaneous meteorological measurements. Dry deposition fluxes of $\mathrm{NO}_{2}$ and $\mathrm{HNO}_{3}$ are inferred using the "big leaf multiple resistance approach" and particle deposition fluxes are derived using an established empirical parameterization. Bi-directional surface-atmosphere exchange fluxes of $\mathrm{NH}_{3}$ and $\mathrm{HONO}$ are estimated by applying a "canopy compensation point model". $\mathrm{N}$ dry and wet deposition is dominated by $\mathrm{NH}_{3}$ and $\mathrm{NH}_{4}^{+}$, which is largely the consequence of biomass burning during the dry season. The
\end{abstract}

Correspondence to: I. Trebs

(ivonne@mpch-mainz.mpg.de) grass surface appeared to have a strong potential for daytime $\mathrm{NH}_{3}$ emission, owing to high canopy compensation points, which are related to high surface temperatures and to direct $\mathrm{NH}_{3}$ emissions from cattle excreta. $\mathrm{NO}_{2}$ also significantly accounted for $\mathrm{N}$ dry deposition, whereas $\mathrm{HNO}_{3}, \mathrm{HONO}$ and $\mathrm{N}$-containing aerosol species were only minor contributors. Ignoring $\mathrm{NH}_{3}$ emission from the vegetation surface, the annual net $\mathrm{N}$ deposition rate is estimated to be about $-11 \mathrm{kgN}$ $\mathrm{ha}^{-1} \mathrm{yr}^{-1}$. If on the other hand, surface-atmosphere exchange of $\mathrm{NH}_{3}$ is considered to be bi-directional, the annual net $\mathrm{N}$ budget at the pasture site is estimated to range from -2.15 to $-4.25 \mathrm{kgN} \mathrm{ha}^{-1} \mathrm{yr}^{-1}$.

\section{Introduction}

The supply of reactive nitrogen $(\mathrm{N})$ to global terrestrial ecosystems has doubled since the 1960s as a consequence of human activities, such as fertilizer application, cultivation of $\mathrm{N}$ fixing legumes and production of nitrogen oxides by fossil-fuel burning (Galloway, 1998). The deposition of atmospheric $\mathrm{N}$ species constitutes a major nutrient input to the biosphere. On a long-term scale, the increase of $\mathrm{N}$ inputs into terrestrial ecosystems may result in (i.) intensified trace gas exchange (ii.) enhanced leaching of nitrate and soil nutrients (e.g., $\mathrm{K}^{+}, \mathrm{Mg}^{2+}, \mathrm{Ca}^{2+}$ ), (iii.) ecosystem eutrophication and acidification, (iv.) reduction in biodiversity, and (v.) increased carbon storage (Vitousek et al., 1997). Enhanced carbon storage due to $\mathrm{N}$ deposition has been shown to increase the terrestrial carbon sink in $\mathrm{N}$-limited temperate

(C) 2006 Author(s). This work is licensed under a Creative Commons License. 
ecosystems, which may have substantial impacts on global $\mathrm{CO}_{2}$ concentrations (e.g., Townsend et al., 1996).

$\mathrm{N}$ deposition is considered to be relevant in the tropics due to widespread biomass burning activity and increasing fertilizer application. It was suggested by e.g., Matson et al. (1999) and Asner et al. (2001) that in contrast to temperate ecosystems, nitrogen-rich/phosphorus (P)-limited tropical rainforest soils may have a reduced productivity following excess $\mathrm{N}$ deposition, resulting in a decreased $\mathrm{C}$ storage. Moreover, the humid tropical zone is a major source area for biogenic nitrous oxide $\left(\mathrm{N}_{2} \mathrm{O}\right)$ and nitric oxide (NO) emissions from soils (Reiners et al., 2002). Enhanced $\mathrm{N}$ inputs to tropical forests are likely to increase nitrification/denitrification rates and, hence, the emission of $\mathrm{NO}$ and $\mathrm{N}_{2} \mathrm{O}$ to the atmosphere (Hall and Matson, 1999). The conversion of tropical rainforest into cultivated land and pasture may lead to a sustained disturbance of the natural $\mathrm{N}$ cycle. During clearing and burning of tropical rainforest, biomassassociated $\mathrm{N}$ is volatilized and a large fraction is emitted in form of gaseous $\mathrm{NH}_{3}$ (Trebs et al., 2004), which may result in considerable $\mathrm{N}$ losses of tropical ecosystems (Kauffman et al., 1998; Kauffman et al., 1995). This is affirmed by the fact that, in contrast to old growth forests, plant growth in deforested areas is suggested to be limited by $\mathrm{N}$ rather than by $\mathrm{P}$ (Davidson et al., 2004; Oliveira et al., 2001).

The deposition of atmospheric $\mathrm{N}$ compounds occurs via dry and wet processes. Nitrogen dioxide $\left(\mathrm{NO}_{2}\right)$, ammonia $\left(\mathrm{NH}_{3}\right)$, nitric acid $\left(\mathrm{HNO}_{3}\right)$ and nitrous acid (HONO) are the most important contributors to $\mathrm{N}$ dry deposition. $\mathrm{HNO}_{3}$ usually features a rapid downward (net deposition) flux to the surface (Huebert and Robert, 1985). By contrast, the exchange of $\mathrm{NO}, \mathrm{NH}_{3}, \mathrm{HONO}$ and $\mathrm{NO}_{2}$ between surface and atmosphere may be bi-directional. The rates of production and consumption in vegetation elements and/or soils as well as the ambient concentration determine whether net emission or net deposition of these species takes place. Turbulent diffusion controls the transport of gases and particles from the surface layer to the Earth's surface. The uptake of trace gases by surfaces is considered to be dependent on physico-chemical and biological surface properties (Hicks et al., 1987), but also on the solubility and reactivity of the gaseous compound (Wesely, 1989). Hence, soil characteristics, plant stomatal activity and trace gas chemical properties largely determine the deposition velocity. The atmospheric dry removal of aerosol particles, which may contain $\mathrm{N}$ species such as ammonium $\left(\mathrm{NH}_{4}^{+}\right)$and nitrate $\left(\mathrm{NO}_{3}^{-}\right)$, is a function of the particle size (Nicholson, 1988) but also depends on the particle density (e.g., Seinfeld and Pandis, 1998). Dry deposition is enhanced for large particles (especially those larger than a few micrometers) due to the additional influence of gravitational settling.

$\mathrm{N}$ wet deposition is a result of in-cloud scavenging ("rainout") and below-cloud scavenging ("washout") of atmospheric N constituents (Meixner, 1994). The total (wet + dry) $\mathrm{N}$ deposition ranges from -1 to $-2 \mathrm{kgN} \mathrm{ha}^{-1} \mathrm{yr}^{-1}$ for rural locations (e.g., North Canada) up to -30 to $-70 \mathrm{kgN}$ $\mathrm{ha}^{-1} \mathrm{yr}^{-1}$ for regions that receive $\mathrm{N}$ from urban pollution and/or agricultural activities (e.g., North Sea, NW Europe and NE U.S.) (Howarth et al., 1996). In contrast to moderately fluctuating air pollution levels that prevail in Europe, the United States and Asia throughout the year, tropical environments such as the Amazon Basin experience every year a dramatic change from the "green ocean" clean background atmosphere to extremely polluted conditions during the biomass burning season. Only few studies exist were atmospheric $\mathrm{N}$ wet removal was determined experimentally in the tropics (Clark et al., 1998; Galloway et al., 1982; Likens et al., 1987; Srivastava and Ambasht, 1994). The chemical composition of precipitation in the Amazon region was determined in previous studies by Andreae et al. (1990), Stallard and Edmond (1981), Lesack and Melack (1991) and Williams et al. (1997). Galy-Lacaux et al. (2003) have estimated $\mathrm{N}$ wet + dry deposition for different (tropical) African ecosystems. However, their dry deposition measurements are based on the application of integrating filter methods which are prone to artifacts (cf. Slanina et al., 2001). Since 1999, N wet + dry deposition are monitored on the Caribbean Virgin islands (St. John Island; see http://www.epa.gov/castnet///sites/vii423.html). Global chemistry and transport models (CTMs) such as MOGUNTIA have been applied to estimate total $\mathrm{N}$ deposition on a global scale (e.g., Holland et al., 1999). Model results suggest that net $\mathrm{N}$ deposition in the northern temperate latitudes exceeds contemporary tropical $\mathrm{N}$ deposition by almost a factor of two. However, reliable experimental information about $\mathrm{N}$ dry deposition in tropical environments, required to validate these model predictions, has been lacking.

Kirkman et al. (2002) determined the surface-atmosphere exchange of $\mathrm{NO}_{\mathrm{x}}\left(\mathrm{NO}+\mathrm{NO}_{2}\right)$ and ozone $\left(\mathrm{O}_{3}\right)$ at a pasture site in the Amazon Basin (Rondônia, Brazil). In this paper, we complement their study by additionally estimating the surface-atmosphere exchange fluxes of $\mathrm{NH}_{3}, \mathrm{HNO}_{3}, \mathrm{HONO}$, aerosol $\mathrm{NO}_{3}^{-}$and $\mathrm{NH}_{4}^{+}$at the same pasture site. Our analysis is based on real-time measurements, supported by simultaneous measurements of meteorological quantities covering the late dry (biomass burning) season, the transition period, and the onset of the wet season (clean conditions). Fluxes of $\mathrm{NO}_{2}, \mathrm{HNO}_{3}, \mathrm{NH}_{3}$ and $\mathrm{HONO}$ are estimated by inferential methods. $\mathrm{N}$ wet deposition was determined by collection of rainwater and subsequent analyses. We estimate the total (wet + dry) annual $\mathrm{N}$ deposition at this pasture site and the relative contribution of the individual $\mathrm{N}$ species.

\section{Experimental}

\subsection{Field site}

Measurements were performed during 12-23 September 2002 (dry season, biomass burning), 7-31 October 2002 
(transition period) and 1-14 November 2002 (wet season, clean conditions) as part of the LBA-SMOCC (Large-Scale Biosphere-Atmosphere Experiment in Amazonia - Smoke, Aerosols, Clouds, Rainfall, and Climate) 2002 campaign (Andreae et al., 2004) at a pasture site in the state of Rondônia, Brazil (Fazenda Nossa Senhora Aparecida, FNS, $10^{\circ} 04.70^{\prime} \mathrm{S}, 61^{\circ} 56.02^{\prime} \mathrm{W}, 145 \mathrm{~m}$ a.s.l.). The site is located in the south-western part of the Amazon Basin. The location and a simplified sketch of the measurement site are shown in Fig. 1. The old growth rain forest at FNS was cleared by slash and burn activities in 1977. The vegetation at FNS is dominated by $\mathrm{C} 4$ grass species (Brachiaria brizantha) with small patches of Brachiaria humidicola and very few isolated palms and bushes, and the site is used as a cattle ranch ( 200 "Blanco" cattle, Bos indicus hybrid). The stocking rate at FNS was about one animal per hectare when field measurements took place. The pasture does not receive any fertilizer and is not harvested. FNS is located within a strip of cleared land about $4 \mathrm{~km}$ wide and several tens of kilometers long (Culf et al., 1996). The towns Ouro Preto do Oeste ( 40 800 inhabitants) and Ji-Paraná ( 110 000 inhabitants) are situated approximately $8 \mathrm{~km}$ and $40 \mathrm{~km}$ to the ENE and ESE of the site, respectively.

The instrumentation for trace gas/aerosol sampling and online analyses was arranged in an air conditioned wooden house. Rain samples were collected nearby the house (see Fig. 1). An automatic weather station (Met 1) was located in a distance of $\sim 20 \mathrm{~m}$ to the $\mathrm{S}$, and a meteorological tower (Met 2) was situated $\sim 200 \mathrm{~m}$ to the NE of the inlets for trace gas and aerosol measurements. While the sampling site provides a sufficient uniform fetch expanding for $1-2 \mathrm{~km}$ from the sampling location in each direction (Andreae et al., 2002), local flow distortions may be caused by the wooden house and some instrument shelters. A more detailed description of the measurement site is given in Andreae et al. (2002) and Kirkman et al. (2002).

\subsection{Sampling and analysis}

Table 1 summarizes the specifications of the instruments for the measurement of trace gases, aerosol species and meteorological quantities. Water-soluble $\mathrm{N}$ containing trace gases $\left(\mathrm{NH}_{3}, \mathrm{HNO}_{3}\right.$ and $\left.\mathrm{HONO}\right)$ and related aerosol species $\left(\mathrm{NH}_{4}^{+}\right.$ and $\mathrm{NO}_{3}^{-}$) were measured on-line. Air was taken from a height of $5.3 \mathrm{~m}$ above ground through a sophisticated inlet system, which was designed to reduce wall losses of soluble gases (especially $\mathrm{HNO}_{3}$ ) and to minimize aerosol losses due to non-isokinetic sampling (see Trebs et al., 2004). Soluble gases were scavenged with a wet-annular denuder (WAD) (Wyers et al., 1993), which was combined with a Steam-JetAerosol Collector (SJAC) (Khlystov et al., 1995) to collect particulate $\mathrm{N}$ species. For both gaseous and aerosol compounds, sample collection was followed by subsequent online analysis (ion chromatography (IC)) for anions and flowinjection analyses (FIA) for $\mathrm{NH}_{4}^{+}$. Cycle times were set to

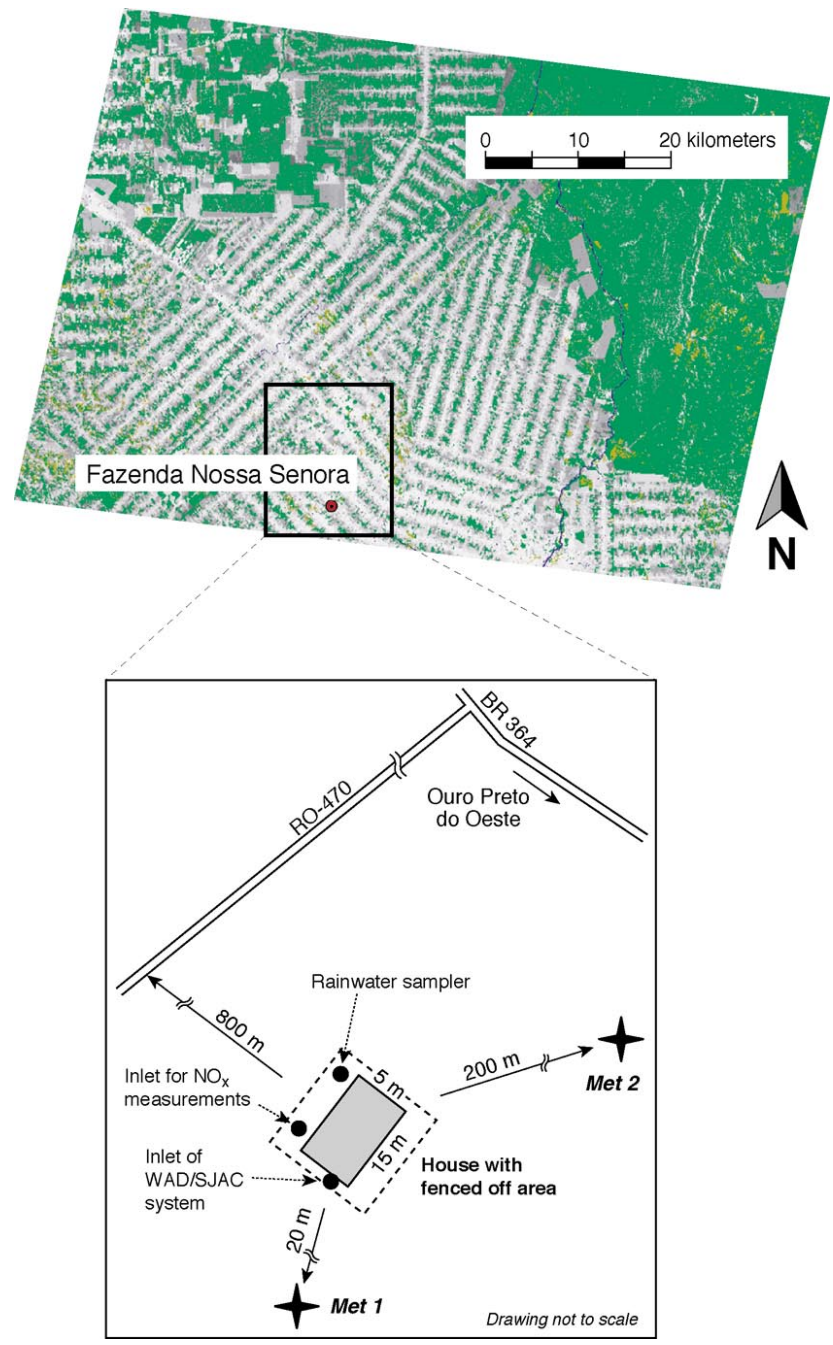

Fig. 1. Location of the LBA-SMOCC measurement site Fazenda Nossa Senhora Aparecida (FNS) in Rondônia, Brazil.

$20 \mathrm{~min}$ (dry season), $40 \mathrm{~min}$ (transition period) and $60 \mathrm{~min}$ (wet season) (Trebs et al., 2004). Aerosol samples of either $\mathrm{PM}_{2.5}\left(D_{p} \leq 2.5 \mu \mathrm{m}\right)$ or total suspended particulate matter (TSP) were collected. A detailed description and verification of the measurement method and of the inlet system can be found in Slanina et al. (2001) and Trebs et al. (2004).

The chemiluminescence $\mathrm{NO} / \mathrm{NO}_{\mathrm{x}}$ analyzer (Thermo Environment Instruments) (see Table 1) was equipped with a molybdenum converter to transform ambient $\mathrm{NO}_{2}$ to $\mathrm{NO}$. However, the converter basically responds to the sum of $\mathrm{NO}_{2}$ $+\mathrm{HNO}_{3}+\mathrm{HONO}+\mathrm{PAN}+$ aerosol $\mathrm{NO}_{3}^{-}+$organic nitrates. Therefore, it is likely that $\mathrm{NO}_{2}$ measurements might be biased by a positive artifact (Fehsenfeld et al., 1990). During our study, the inlet line for $\mathrm{NO} / \mathrm{NO}_{\mathrm{x}}$ measurements had a length of $25 \mathrm{~m}$ (inner diameter $=4.4 \mathrm{~mm}$ ). Therefore, highly soluble and sticky species such as $\mathrm{HNO}_{3}$ and $\mathrm{HONO}$ are assumed to be at least partly removed within the long inlet 
Table 1. Specifications of the instrumentation for the measurement of trace gases, aerosol species and meteorological quantities at FNS during LBA-SMOCC 2002 (all heights are above ground).

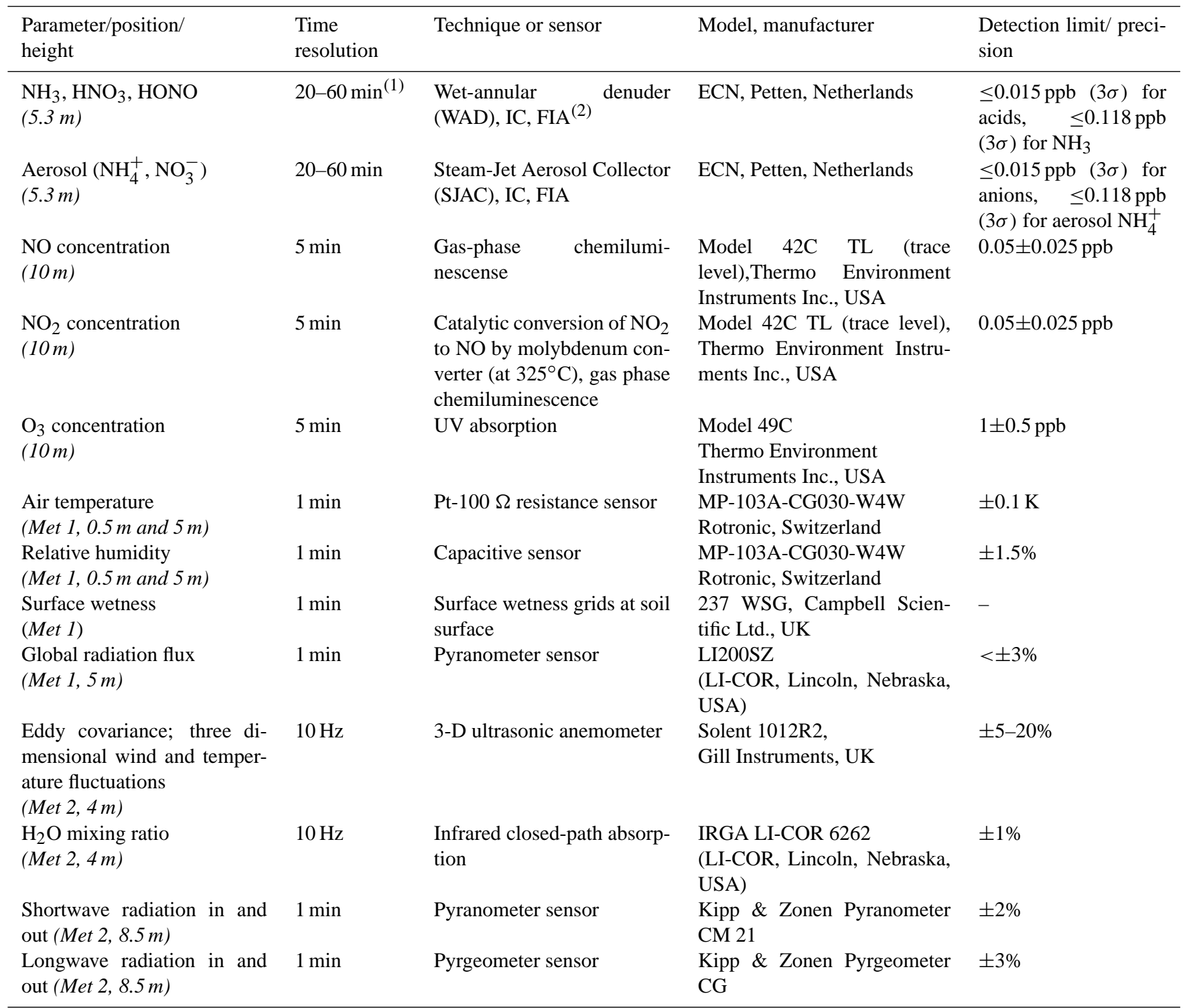

(1) 20 min: dry season (12-13 September), 40 min: transition period (7-31 October), 60 min: wet season (1-14 November)

(2) IC: ion chromatography, FIA: flow injection analysis

tubing. In addition, mixing ratios of $\mathrm{HNO}_{3}$ and $\mathrm{HONO}$ were usually below $0.5 \mathrm{ppb}$ (Trebs et al., 2004), indicating that interferences would be marginal in case any of these gases would reach the chemiluminescence analyzer. However, elevated emissions of isoprene in the area may result in considerable concentrations of PAN such that we may not rule out interferences due to this compound. Aerosol $\mathrm{NO}_{3}^{-}$was eliminated by the application of an inlet filter.

Also listed in Table 1 are those meteorological sensors that were used to measure the quantities involved in this study, namely air temperature $(T)$, relative humidity $(R H)$, surface wetness, global radiation flux, momentum, latent and sensible heat flux and ingoing/outgoing short- and longwave radiation. Eddy covariance measurements were conducted using a Gill 3D-sonic anemometer. The $\mathrm{H}_{2} \mathrm{O}$ mixing ratio was monitored by a fast LI-COR infrared gas analyzer, and its analog output was directly fed to the ultrasonic anemometer $\mathrm{A} / \mathrm{D}$ converter. Post-processing of the eddy covariance data (EDDYWSC, software by Alterra, Wageningen University Research, Netherlands) resulted in $30 \mathrm{~min}$ averages 
of sensible heat flux, latent heat flux, friction velocity and Monin-Obukov length. More details on the eddy covariance measurements and corresponding data evaluation/calibration procedures are given in Araujo et al. (2002).

Precipitation was sampled from 12 September to 14 November 2002 using a wet-only rainwater collector (Aerochem Metrics). A total of 23 rainstorm events were collected representing $\sim 100 \%$ of the precipitation in this period. Rain samples were stored in the dark at $4^{\circ} \mathrm{C}$ using polyethylene bottles which were previously cleaned with deionized water and preserved with Thymol. In order to trace possible contaminations, the sample $\mathrm{pH}$ was measured directly after sampling and before analysis. Analyses of $\mathrm{NH}_{4}^{+}, \mathrm{NO}_{3}^{-}$and $\mathrm{NO}_{2}^{-}$were performed for all samples using a Dionex DX600 ion chromatograph at the Laboratório de Ecologia Isotópica, CENA/USP (São Paulo, Brazil). The detection limit was $0.05 \mu \mathrm{M}$ for all species. More details about sampling and analysis procedures are provided by Lara et al. (2001).

Moreover, a twin Differential Mobility Particle Sizer (DMPS) was employed to measure the dry aerosol particle size distribution in the diameter range from 3 to $850 \mathrm{~nm}$ (cf. Rissler et al., 2004). The size distribution of particles with aerodynamic diameters from 1 to $4 \mu \mathrm{m}$ was measured with an Aerodynamic Particle Sizer (TSI APS 3310).

\section{Theory: Estimation of $\mathbf{N}$ dry and wet deposition}

\subsection{Trace gas fluxes}

Dry deposition fluxes of trace gases have been estimated using the inferential method, which is based on the "big leaf multiple resistance approach" (Wesely and Hicks, 1977; Hicks et al., 1987). The deposition flux $(F)\left(\mu \mathrm{g} \mathrm{m}^{-2} \mathrm{~s}^{-1}\right)$ of a nonreactive trace gas for which the surface is a sink under all ambient conditions is defined by:

$F=-V_{d} \cdot X\left(z_{\text {ref }}\right)=-\frac{X\left(z_{\text {ref }}\right)}{R_{a}+R_{b}+R_{c}}$

where $X\left(z_{\text {ref }}\right)$ is the trace gas concentration $\left(\mu \mathrm{g} \mathrm{m}^{-3}\right)$ at the reference height $z_{\text {ref }}(\mathrm{m})$ and $V_{d}$ denotes the dry deposition velocity $\left(\mathrm{m} \mathrm{s}^{-1}\right)$, which is the reciprocal of the sum of the turbulent resistance $\left(R_{a}\right)\left(\mathrm{s} \mathrm{m}^{-1}\right)$, the quasi-laminar or viscous boundary layer resistance $\left(R_{b}\right)\left(\mathrm{s} \mathrm{m}^{-1}\right)$, and the surface resistance $\left(R_{c}\right)\left(\mathrm{s} \mathrm{m}^{-1}\right)$. According to Hicks et al. (1987) $R_{a}$ between the reference height $\left(z_{\text {ref }}\right)$ and the roughness length $z_{0}(\mathrm{~m})$ is given by:

$R_{a}=\frac{1}{\kappa \times u_{*}}\left[\ln \left(\frac{z_{\text {ref }}}{z_{0}}\right)-\Psi_{H_{\left(\frac{\text { ref }}{L}\right)}}\right]$

where $\kappa$ denotes the von Karman constant $(0.41)$ and $L$ is the Monin-Obukov length (m), a measure of atmospheric stability that is derived from the sensible heat flux and the friction velocity $u_{*}$ (Garratt, 1992). $\Psi_{H}\left(z_{\text {ref }} / L\right)$ is the stability correction function for heat and inert tracers in its integral form (see Thom, 1975). The roughness length $z_{0}$ of the grass surface at the FNS site was taken as $0.11 \mathrm{~m}$ (cf. Kirkman et al., 2002) and $z_{\text {ref }}$ was $5.3 \mathrm{~m}$ and $10 \mathrm{~m}$ for the WAD/SJAC and for the $\mathrm{NO}_{\mathrm{x}}$ measurements, respectively (Table 1). To account for conditions when the reliability of micrometeorological techniques was low, data were rejected for $u_{*} \leq 0.01 \mathrm{~m}$ $\mathrm{s}^{-1}$ and $z_{\text {ref }} / L \geq 5$, i.e. when extremely low turbulence and/or very high thermal stability was prevailing. Also, data were rejected for $z_{\text {ref }} / L \leq-5$, which reflects cases of very high thermal turbulence production (when Monin-Obukov similarity is no longer valid (Ammann, 1999). Thus, about 10\% of the dataset were not used for the flux calculations.

$R_{b}$ determines the exchange of gaseous matter by molecular-turbulent diffusion across the viscous laminar sublayer immediately above the vegetation elements and can be described by (Hicks et al., 1987):

$R_{b}=\frac{2}{\kappa \times u_{*}}\left(\frac{S c}{P r}\right)^{\frac{2}{3}}$

where $S c$ and $P r$ are the Schmidt and Prandtl number, respectively. $P r$ is 0.72 and $S c$ is a strong function of the molecular diffusivity of the trace gas. Values for $S c$ were taken from Hicks et al. (1987) and Erisman et al. (1994) for the different trace gas species. The surface resistances $R_{c}$ could not be directly determined from our field measurements; hence values were adopted from the literature (see Sect. 4.4).

The inferential method is valid for trace gases whose mixing ratio just above the soil and/or vegetation elements is zero. The observation of a net $\mathrm{NO}_{2}$ deposition flux to the FNS pasture by Kirkman et al. (2002) justifies the application of the inferential model for $\mathrm{NO}_{2}$ in our study. This is also valid for $\mathrm{HNO}_{3}$, which typically features a rapid downward flux with negligible $R_{c}$ and corresponding high $V_{d}$ (Hanson and Lindberg, 1991).

By contrast, $\mathrm{NO}, \mathrm{HONO}$ and $\mathrm{NH}_{3}$ may be both deposited to and emitted from surfaces. Formally, this can be accounted for by a so-called canopy compensation point concentration $X_{c}\left(\mu \mathrm{g} \mathrm{m}^{-3}\right)$ that generally refers to the concentration of the compound just above the soil and/or vegetation elements (Nemitz et al., 2004a). $X_{c}$ represents a concentration analogue of $R_{c}$ and is the air concentration at which competing chemical and biological consumption and production processes balance each other (i.e., the net flux is zero) (see Sutton et al., 1995):

$$
F=\frac{X_{c}-X\left(z_{\text {ref }}\right)}{R_{a}+R_{b}}
$$

The net NO emission from the FNS pasture site determined by Kirkman et al. (2002) was very low $\left(0.65 \mathrm{ngN} \mathrm{m}^{-2} \mathrm{~s}^{-1}\right.$ or $0.17 \mathrm{kgN} \mathrm{ha}^{-1} \mathrm{yr}^{-1}$ ), thus we neglected any contribution of NO to the surface-atmosphere exchange of $\mathrm{N}$ species in our study. HONO is generally assumed to be formed by heterogeneous reaction of $\mathrm{NO}_{2}$ with surface water (Harrison et al., 1996) and it may subsequently be emitted from 
plant foliar cuticles or soil surfaces. Since there is no indication for any direct HONO emissions by plants (Schimang et al., 2006), the HONO compensation point concentration $X_{c}(\mathrm{HONO})$ is expected to be a function of the $\mathrm{NO}_{2}$ mixing ratio (see Sect. 4.4).

To predict the bi-directional surface-atmosphere exchange of $\mathrm{NH}_{3}$ at the FNS site, we applied a dynamic resistance model proposed by Sutton et al. (1998). Besides uptake and emission of $\mathrm{NH}_{3}$ via plant stomata, the dynamic model accounts for absorption of $\mathrm{NH}_{3}$ by epicuticular water films under very humid conditions, and subsequent re-evaporation (capacitive leaf surface exchange). Since the FNS site is used as a cattle ranch and the $\mathrm{NH}_{3}$ flux directly from the soil is assumed to be negligible compared to that originating from cattle excreta, we considered a direct $\mathrm{NH}_{3}$ flux from cattle manure and urine $F\left(\mathrm{NH}_{3}\right)_{e}$. The net $\mathrm{NH}_{3}$ flux $F\left(\mathrm{NH}_{3}\right)$ can be related directly to the $\mathrm{NH}_{3}$ canopy compensation point concentration $X_{c}\left(\mathrm{NH}_{3}\right)$ (Sutton et al., 1998) and is composed of its component fluxes through plant stomata, $F_{s}\left(\mathrm{NH}_{3}\right)$, the flux in or out of the epicuticular water film (adsorption capacitor), $F_{d}\left(\mathrm{NH}_{3}\right)$, and $F\left(\mathrm{NH}_{3}\right)_{e}$ :

$$
\begin{aligned}
F\left(\mathrm{NH}_{3}\right)_{t} & =\underbrace{\frac{X_{s}\left(\mathrm{NH}_{3}\right)-X_{c}\left(\mathrm{NH}_{3}\right)}{F s\left(\mathrm{NH}_{3}\right)}}_{R_{s}\left(\mathrm{NH}_{3}\right)} \\
& +\underbrace{\frac{X_{d}\left(\mathrm{NH}_{3}\right)}{F d\left(\mathrm{NH}_{3}\right)}}_{R_{d}\left(\mathrm{NH}_{3}\right)}+F\left(\mathrm{NH}_{3}\right)_{e} \\
& =\frac{X_{c}\left(\mathrm{NH}_{3}\right)-X\left(\mathrm{NH}_{3}, z_{\mathrm{ref}}\right)}{R_{a}+R_{b}}
\end{aligned}
$$

where $X_{s}\left(\mathrm{NH}_{3}\right)$ denotes the $\mathrm{NH}_{3}$ stomatal compensation point concentration $\left(\mu \mathrm{g} \mathrm{m}^{-3}\right)$ and $R_{S}\left(\mathrm{NH}_{3}\right)$ denotes the $\mathrm{NH}_{3}$ stomatal resistance $\left(\mathrm{s} \mathrm{m}^{-1}\right) . X_{d}\left(\mathrm{NH}_{3}\right)_{t}$ is the $\mathrm{NH}_{3}$ adsorption concentration $\left(\mu \mathrm{g} \mathrm{m}^{-3}\right)$ associated with the "leaf surface capacitor" at time step $t$ and $R_{d}\left(\mathrm{NH}_{3}\right)$ is the charging resistance of the capacitor $\left(\mathrm{s} \mathrm{m}^{-1}\right)$ (see Sutton et al., 1998). $X_{c}\left(\mathrm{NH}_{3}\right)$ is then determined by Sutton et al. (1998):

$X_{c}\left(\mathrm{NH}_{3}\right)_{t}=$

$\frac{X\left(\mathrm{NH}_{3}, \mathrm{z}_{\mathrm{ref}}\right) /\left(R_{a}+R_{b}\right)+X_{s}\left(\mathrm{NH}_{3}\right) / R_{s}\left(\mathrm{NH}_{3}\right)+X_{d}\left(\mathrm{NH}_{3}\right)_{t} / R_{d}\left(\mathrm{NH}_{3}\right)+F\left(\mathrm{NH}_{3}\right)_{e}}{\left(R_{a}+R_{b}\right)^{-1}+R_{s}\left(\mathrm{NH}_{3}\right)^{-1}+R_{d}\left(\mathrm{NH}_{3}\right)^{-1}}$

$X_{s}\left(\mathrm{NH}_{3}\right)$ can be parameterized according to (Farquhar et al., 1980; Sutton et al., 1994):

$X_{S}\left(\mathrm{NH}_{3}\right)=\frac{161512}{T_{S}} \cdot 10^{\left(-4507.11 / T_{S}\right)} \cdot \Gamma \cdot 17000$

where $T_{S}$ is the surface temperature $(K)$ which was derived from the outgoing longwave radiation by applying the Stefan-Boltzmann law. $\Gamma$ is the ratio of apoplastic $\left[\mathrm{NH}_{4}^{+}\right] /\left[\mathrm{H}^{+}\right]$and was adopted from the literature (Sect. 4.4). $R_{S}\left(\mathrm{NH}_{3}\right)$ can be calculated from the measured latent heat flux for relatively dry daytime conditions and in the absence of precipitation according to Nemitz et al. (2004a) (see
Sect. 4.4). Furthermore, $X_{d}\left(\mathrm{NH}_{3}\right)$ at time step $t$ is a function of the adsorption charge and of the capacitance of the epicuticular water film (for details see Sutton et al., 1998). The values for the adsorption charge were adopted from Sutton et al. (1998) and the capacitance is a function of the epicuticular pH (see Sect. 4.4)

\subsection{Aerosol fluxes}

Up to date, no well established bulk resistance models exist for the dry deposition of particles. Significant discrepancies have been observed between experimental results and model predictions (Ruijgrok et al., 1995). The theoretical framework proposed by Slinn (1982) is widely used in modeling studies to predict particle deposition velocities. However, Wesely et al. (1985) derived an empirical parameterization for the dry deposition velocity $V_{p}\left(\mathrm{~m} \mathrm{~s}^{-1}\right)$ of submicron sulfate aerosols $\left(D_{p}=0.1-1.0 \mu \mathrm{m}\right)$ to grass surfaces:

$V_{p}=u_{*} \cdot 0.002, \quad$ for $L \geq 0$

$V_{p}=u_{*} \cdot 0.002 \cdot\left[1+\left(\frac{-a}{L}\right)^{\frac{2}{3}}\right], \quad$ for $L<0$

where $a=300 \mathrm{~m}$. This approach generally results in much higher $V_{p}$ values for submicron particles than predicted by the Slinn model. Several other studies (e.g., Garland, 2001; Nemitz et al., 2004b; Vong et al., 2004) also showed that $V_{p}$ to surfaces of low aerodynamic roughness may be much larger than predicted by the Slinn model, even for particles of different chemical composition than studied by Wesely et al. (1985). In this study either $\mathrm{PM}_{2.5}$ or TSP was sampled. $\mathrm{NH}_{4}^{+}$is known to be largely attributed to fine mode aerosols with $D_{p} \leq 1.0 \mu \mathrm{m}$ (Seinfeld and Pandis, 1998), which was also observed during the SMOCC measurement campaign (Fuzzi et al., 2005 ${ }^{1}$ ). By contrast, aerosol $\mathrm{NO}_{3}^{-}$exhibited a bimodal size distribution (Falkovich et al., 2005). Since we did not find an empirical relationship in the literature to estimate $V_{p}$ for aerosols with $D_{p} \geq 1.0 \mu \mathrm{m}$ and the contribution of coarse mode aerosol $\mathrm{NO}_{3}^{-}$relative to that of fine mode aerosol $\mathrm{NH}_{4}^{+}$is presumably small (cf. Sect. 4.2, Table 2), the parameterization by Wesely et al. (1985) is considered as a reasonable approximation for both $\mathrm{PM}_{2.5}$ and TSP samples.

\footnotetext{
${ }^{1}$ Fuzzi, S., Decesari, S., Facchini, M. C., Cavalli, F., Emblico, L., Mircea, M., Andreae, M. O. Trebs, I., Hoffer, A., Guyon, P., Artaxo, P., Rizzo, L. V., Lara, L. L., Pauliquevis, T., Maenhaut, W., Raes, N., Chi, X., Mayol-Bracero, O. L., Soto, L., Claeys, M., Kourtchev, I., Rissler, J., Swietlicki, E., Tagliavini, E., Schkolnik, G., Falkovich, A. H., Rudich, Y., Fisch, G., and Gatti, L. V. : Overview of the inorganic and organic composition of sizesegregated aerosol in Rondônia, Brazil, from the biomass burning period to the onset of the wet season, J. Geophys. Res., submitted, 2005
} 
Table 2. Summary of trace gas and aerosol mixing ratios $\left.{ }^{*}\right)$ during the dry season (12-13 September), the transition period (7-31 October) and the wet season (1-14 November) at FNS during LBA-SMOCC 2002 (conversion factors from ppb to $\mu \mathrm{g} \mathrm{m}^{-3}$ for standard conditions of $298.15 \mathrm{~K}$ and $1000 \mathrm{hPa}$ : NO: $1.21, \mathrm{NO}_{2}: 1.86, \mathrm{O}_{3}: 1.94, \mathrm{NH}_{3}: 0.69, \mathrm{HNO}_{3}: 2.54, \mathrm{HONO}: 1.89$, aerosol $\mathrm{NH}_{4}^{+}: 0.73$, aerosol $\mathrm{NO}_{3}^{-}: 2.77$ ).

\begin{tabular}{lccccccccccccc}
\hline & \multicolumn{3}{c}{ Dry season } & \multicolumn{3}{c}{ Transition period } & \multicolumn{4}{c}{ Wet season } \\
\hline Species & $\mathrm{m}$ & $\mathrm{P} \mathrm{0.25}$ & $\mathrm{P} \mathrm{0.75}$ & $\mathrm{n}$ & $\mathrm{m}$ & $\mathrm{P} \mathrm{0.25}$ & $\mathrm{P} \mathrm{0.75}$ & $\mathrm{n}$ & $\mathrm{m}$ & $\begin{array}{c}\mathrm{P} \mathrm{0.25} \\
(\mathrm{ppb})\end{array}$ & $\begin{array}{c}\mathrm{P} 0.75 \\
(\mathrm{ppb})\end{array}$ & $\begin{array}{c}\mathrm{n} \\
(X)\end{array}$ \\
& $(\mathrm{ppb})$ & $(\mathrm{ppb})$ & $(\mathrm{ppb})$ & $(X)$ & $(\mathrm{ppb})$ & $(\mathrm{ppb})$ & $(\mathrm{ppb})$ & $(X)$ & $(\mathrm{ppb})$ & $(\mathrm{ppb})$ \\
$\mathrm{NO}$ & 0.09 & 0.07 & 0.15 & 372 & 0.09 & 0.07 & 0.17 & 295 & 0.12 & 0.07 & 0.13 & 229 \\
$\mathrm{NO}_{2}$ & 4.54 & 2.85 & 6.46 & 630 & 1.78 & 1.23 & 2.56 & 697 & 1.07 & 0.82 & 1.76 & 268 \\
$\mathrm{O}_{3}$ & 24.3 & 11.76 & 34.87 & 826 & 25.59 & 15.91 & 32.95 & 781 & 14.74 & 10.77 & 19.39 & 316 \\
$\mathrm{NH}_{3}$ & 1.81 & 1.10 & 2.91 & 298 & 1.06 & 0.5 & 1.74 & 236 & 0.55 & 0.38 & 0.85 & 60 \\
$\mathrm{HNO}_{3}$ & 0.16 & 0.10 & 0.25 & 317 & 0.06 & 0.03 & 0.13 & 210 & 0.06 & 0.04 & 0.08 & 52 \\
$\mathrm{HONO}$ & 0.12 & 0.08 & 0.27 & 323 & 0.07 & 0.05 & 0.09 & 315 & 0.06 & 0.04 & 0.07 & 139 \\
Aerosol NH & 1.01 & 0.73 & 1.51 & 291 & 0.54 & 0.33 & 0.85 & 267 & 0.47 & 0.32 & 0.62 & 66 \\
Aerosol NO & - & 0.34 & 0.17 & 0.61 & 297 & 0.09 & 0.06 & 0.15 & 282 & 0.06 & 0.04 & 0.07 & 33 \\
\hline
\end{tabular}

${ }^{(*)} \mathrm{m}$ : median, $\mathrm{P} 0.25$ : 0.25 percentile, $\mathrm{P} 0.75: 0.75$ percentile, $\mathrm{n}$ : number of determined data points above the limit of detection (for aerosol species $\mathrm{PM}_{2.5}$ and bulk measurements were included). $\mathrm{NO}_{\mathrm{x}} / \mathrm{O}_{3}$ data were synchronized to the WAD/SJAC data.

\subsection{Determination of characteristic time scales}

The resistance-based approaches presented above to calculate surface-atmosphere exchange fluxes rely on the "constant flux layer assumption", which implies that the trace compounds are considered as chemically-non-reactive tracers, such that their flux within the atmospheric surface layer is constant. However, sufficiently accurate fluxes of compounds that undergo rapid chemical transformation can be estimated as long as characteristic chemical time scales are one order of magnitude larger than turbulent transport times (Damköhler ratio $D_{r}<0.1$ ) (De Arellano and Duynkerke, 1992). Following De Arellano and Duynkerke (1992) the characteristic time of turbulent transport $\tau_{\text {turb }}(\mathrm{s})$ can be calculated as:

$\tau_{\text {turb }}=\kappa \cdot\left(z_{\text {ref }}+z_{0}\right) \cdot \frac{u_{*}}{\sigma_{w}^{2}}$

where $\sigma_{w}$ denotes the standard deviation of the vertical wind component $\left(\mathrm{m} \mathrm{s}^{-1}\right)$. Atmospheric stability strongly determines the time scale of turbulent transport, which typically ranges from a couple of seconds under unstable conditions up to $2.5 \mathrm{~h}$ under stable conditions (for a layer of $10 \mathrm{~m}$ height) (Dlugi, 1993).

For the characteristic chemical time scale of the NO$\mathrm{NO}_{2}-\mathrm{O}_{3}$ triad, its photo-stationary equilibrium has to be considered. $\mathrm{NO}_{2}$ is rapidly photolyzed to $\mathrm{NO}$ in the troposphere and it is re-formed by reaction of $\mathrm{NO}$ with $\mathrm{O}_{3}$. The overall chemical time scale of the NO$\mathrm{NO}_{2}-\mathrm{O}_{3}$ triad $\tau\left(\mathrm{NO}-\mathrm{NO}_{2}-\mathrm{O}_{3}\right)$ is given by the combination of $\tau(\mathrm{NO})=\left(\mathrm{k}_{2} \times\left[\mathrm{O}_{3}\right]\right)^{-1}, \tau\left(\mathrm{NO}_{2}\right)=k_{1}^{-1}=j\left(\mathrm{NO}_{2}\right)^{-1}$ and $\tau\left(\mathrm{O}_{3}\right)=\left(k_{2} \times[\mathrm{NO}]\right)^{-1}$ (Lenschow, 1982) (where $k$ is the reaction rate constant) and was calculated in accordance to
Kirkman et al. (2002). Thereby, $j\left(\mathrm{NO}_{2}\right)$ was estimated from global radiation data using a relation derived from simultaneous measurements of global radiation and $j\left(\mathrm{NO}_{2}\right)$ in Amazonia during LBA-EUSTACH (cf. Kirkman et al., 2002).

HONO is rapidly photolyzed during daylight hours. The chemical time scale for daytime HONO photolysis is given by $\tau(\mathrm{HONO})_{\text {photol. }}=j(\mathrm{HONO})^{-1}$, whereby the parameterization provided by Kraus and Hofzumahaus (1998) was used to relate $j(\mathrm{HONO})$ to $j\left(\mathrm{NO}_{2}\right)$. The chemical time scale of heterogeneous HONO formation at nighttime $\tau(\mathrm{HONO})_{\text {het. was }}$ derived by considering the $\mathrm{HONO}$ production rate $P_{\mathrm{HONO}}$ $\left(\mathrm{ppb} \mathrm{h}^{-1}\right.$ ) determined directly from our measurements (see Sect. 4.3). Homogeneous daytime HONO formation may proceed via reaction of $\mathrm{NO}$ with $\mathrm{OH}$ radicals; however, this process is very slow and can be neglected compared to daytime HONO photolysis (Lammel and Cape, 1996).

Photochemical reactions involving $\mathrm{NH}_{3}$ and $\mathrm{HNO}_{3}$ are not considered to contribute to any flux divergence since their chemical time scale is much larger than the time scale of turbulent transport (Pandis et al., 1995). By contrast, time scales to achieve gas/aerosol equilibrium between gaseous $\mathrm{NH}_{3}, \mathrm{HNO}_{3}$ and particulate $\mathrm{NH}_{4} \mathrm{NO}_{3}$ may occur within the time frame of turbulent transport (few seconds for submicron particles) and have to be explicitly considered here (Dlugi, 1993; Meng and Seinfeld, 1996). As reported by Trebs et al. (2005), the measured concentration product of $\mathrm{NH}_{3} \times \mathrm{HNO}_{3}$ was persistently below the theoretical equilibrium dissociation constant of the pure $\mathrm{NH}_{3} / \mathrm{HNO}_{3} / \mathrm{NH}_{4} \mathrm{NO}_{3}$ system during daytime $(\mathrm{RH}<90 \%)$, but approached the theoretical equilibrium value during nighttime $(\mathrm{RH}>90 \%)$. The desired equilibration time scale $\tau\left(\mathrm{NH}_{3}-\mathrm{HNO}_{3}-\mathrm{NH}_{4} \mathrm{NO}_{3}\right)$ 
can be estimated according to (Wexler and Seinfeld, 1992):

$$
\begin{array}{r}
\tau\left(\mathrm{NH}_{3}-\mathrm{HNO}_{3}-\mathrm{NH}_{4} \mathrm{NO}_{3}\right)^{-1} \\
=3 \bar{D} \times \int_{0}^{\infty} \frac{m\left(R_{p}\right) d R_{p}}{\left(1+\frac{\lambda}{\alpha+R_{p}}\right) \times R_{p}^{2} \times \rho_{p}}
\end{array}
$$

whereby the aerosol mass size distribution $m\left(R_{p}\right) d R_{p}$ was related to the measured aerosol number size distribution. $R_{p}$ is the particle radius (m), $\bar{D}$ is the geometric mean of the diffusivity of semi-volatile gaseous species $\left(\mathrm{m}^{2} \mathrm{~s}^{-1}\right), m$ is the water-soluble particle mass $\left(\mathrm{kg} \mathrm{m}^{-3}\right), \lambda$ is the mean free path of air $\left(6.51 \times 10^{-8} \mathrm{~m}\right.$ at $\left.293.15 \mathrm{~K}\right), \alpha$ denotes the accommodation coefficient $(0.001<\alpha<1)$ (Wexler and Seinfeld, 1990), and $\rho_{p}$ is the particle density. A value of $\rho_{p}=1.35 \pm 0.15 \mathrm{~g} \mathrm{~cm}^{-3}$ was used as determined by Reid and Hobbs (1998) for Amazonian biomass burning aerosols.

The comparison of $\tau_{\text {turb }}$ with $\tau\left(\mathrm{NO}-\mathrm{NO}_{2}-\mathrm{O}_{3}\right)$, $\tau(\mathrm{HONO})_{\text {photol. }}, \tau(\mathrm{HONO})_{\text {het. }}$ and $\tau\left(\mathrm{NH}_{3}-\mathrm{HNO}_{3}-\mathrm{NH}_{4} \mathrm{NO}_{3}\right)$ provides a test whether reactive species can be treated as a passive tracer during their vertical transport within the surface layer $\left(D_{r}<0.1\right)$ and, consequently, if the application of the "big leaf multiple resistance approach" and the "canopy compensation point model" are justifiable.

\subsection{N wet deposition}

Storm size influences the chemical composition of the rainwater, in the sense that larger storms tend to be more dilute. This dependence demands the use of volume weighted means (VWM) for the calculation of monthly and annual concentration averages. For each rainwater solute, the concentrations measured in the sample were combined to create a VWM concentration for each collection date:

$V W M_{a}=\frac{\sum_{i=1}^{n} c_{a i} \times v_{i}}{\sum v_{i}}$

where $c_{a i}$ is the concentration of species $a$ in sample $i, n$ is the number of samples and $v_{i}$ is the volume of precipitation solution for sample $i$. The rain water concentrations measured during SMOCC were extrapolated to the whole year. Since storm size can vary from year to year we used long-term rainfall amounts to obtain the annual $\mathrm{N}$ deposition rate (cf. Lara et al., 2001). Rainfall amounts and air mass trajectories during the SMOCC period were comparable to conditions during the same period of previous years. Thus, these months can be considered as representative of the meteorological conditions during this period in this area. The $\mathrm{N}$ wet deposition rates for September, October and November were derived by summation of the VWM concentration determined for each precipitation event throughout the month, and subsequent multiplication by the mean of rainfall in the respective month obtained from historical time series (see http://www.aneel.gov.br). The annual $\mathrm{N}$ wet deposition was derived in a similar way; for instance, the VWM concentration obtained during September was considered as representative of the entire dry season and then multiplied by the historical mean rainfall for the dry season. The same procedure was performed for October and November representing transition period and wet season, respectively.

\section{Results and Discussion}

In the following, the general patterns of our results will be shown as diel courses of the medians of measured and inferred quantities. Diel courses will be presented either for part of the dry season (biomass burning, 12-23 September) or, where the investigated quantities are relatively independent of season, for the entire measurement campaign (12 September-14 November 2002). To derive surfaceatmosphere exchange fluxes of $\mathrm{N}$-containing compounds, meteorological data and $\mathrm{NO}_{\mathrm{x}} / \mathrm{O}_{3}$ data were synchronized to the time resolution of the WAD/SJAC system. The convention of negative downward fluxes (net deposition) and positive upward fluxes (net emission) has been adopted.

\subsection{Meteorological conditions}

In the Amazon Basin, nighttime radiative cooling usually results in the formation of a shallow, decoupled nocturnal boundary layer of high thermodynamic stability characterized by very low wind speeds; while the development of a deepening, convectively mixed layer starts with the heating of the surface in the morning (Nobre et al., 1996; Fisch et al., 2004). Median nighttime wind speeds (at height $z=5.0 \mathrm{~m}$ ) at FNS were low $\left(\leq 1 \mathrm{~m} \mathrm{~s}^{-1}\right)$. By contrast, wind speeds were substantially higher during daytime, ranging from 2 to $3 \mathrm{~m} \mathrm{~s}^{-1}$. The $24-\mathrm{h}$ average friction velocity $\left(u_{*}\right)$ was $\sim 0.16 \mathrm{~m} \mathrm{~s}^{-1}$ and reached maxima of $\sim 0.4 \mathrm{~m} \mathrm{~s}^{-1}$ around noon. Differences of $u_{*}$ between the dry season, the transition period, and the wet season were marginal. As a consequence of high global radiation fluxes $\left(500-900 \mathrm{~W} \mathrm{~m}^{-2}\right.$, median) during daytime, ambient temperatures at the FNS site $(z=5.0 \mathrm{~m})$ ranged between 30 and $36^{\circ} \mathrm{C}$ during sunlight hours, while nighttime temperatures were much lower $(20$ $\left.25^{\circ} \mathrm{C}\right)$. High relative humidities $(R H s)(z=5.0 \mathrm{~m})$ were observed during nighttime (90-100\%), while daytime $R H$ values usually dropped to $40-50 \%$ during afternoon hours. Local meteorology changed only marginally from the dry season to the wet season. Strong rain events $\left(\geq 30 \mathrm{~mm} \mathrm{~h}^{-1}\right)$ occurred in the afternoon hours during the transition period and the wet season. A more detailed description of diel meteorological conditions is presented by Trebs et al. (2005).

\subsection{Mixing ratios}

Median diel variations of mixing ratios of $\mathrm{NO}, \mathrm{NO}_{2}, \mathrm{O}_{3}$, $\mathrm{NH}_{3}, \mathrm{HNO}_{3}, \mathrm{HONO}$ and the inorganic aerosol species $\mathrm{NH}_{4}^{+}$ and $\mathrm{NO}_{3}^{-}$are shown in Fig. $2 \mathrm{a}-\mathrm{h}$ for 12 to 23 September (dry 

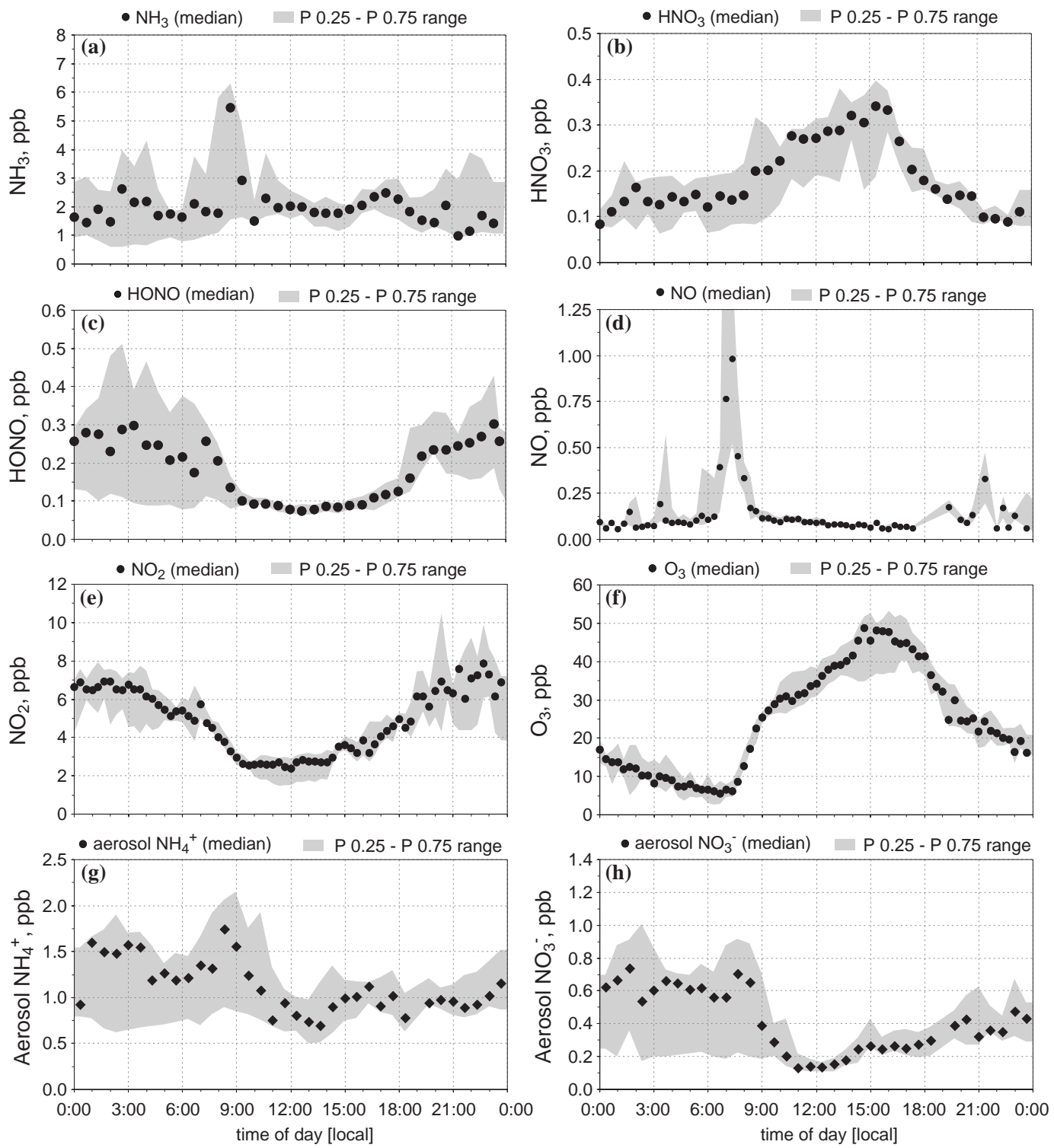

Fig. 2. Diel variations of (a) $\mathrm{NH}_{3}$, (b) $\mathrm{HNO}_{3}$, (c) $\mathrm{HONO}$, (d) $\mathrm{NO}$, (e) $\mathrm{NO}_{2}$, (f) $\mathrm{O}_{3}$, (g) aerosol $\mathrm{NH}_{4}^{+}\left(\mathrm{PM}_{2.5}\right.$ ) and (h) aerosol NO$-\left(\mathrm{PM}_{2.5}\right.$ ) measured during 12-23 September 2002 (dry season, biomass burning) at FNS during LBA-SMOCC 2002 (conversion factors from ppb to $\mu \mathrm{g} \mathrm{m}^{-3}$ for standard conditions of $298.15 \mathrm{~K}$ and $1000 \mathrm{hPa}: \mathrm{NH}_{3}: 0.69, \mathrm{HNO}_{3}: 2.54, \mathrm{HONO}: 1.89, \mathrm{NO}: 1.21, \mathrm{NO}_{2}: 1.86, \mathrm{O}_{3}: 1.94$, aerosol $\mathrm{NH}_{4}^{+}: 0.73$, aerosol $\left.\mathrm{NO}_{3}^{-}: 2.77\right)$. Symbols and grey shading represent medians and interquartile ranges $(0.25$ to 0.75 percentiles $)$, respectively.

season, biomass burning). Table 2 summarizes ambient mixing ratios measured during the dry season (12-23 September), the transition period (7-31 October) and the wet season (1-14 November). A detailed discussion of seasonal and diel cycles observed for $\mathrm{NH}_{3}, \mathrm{HNO}_{3}, \mathrm{HONO}$ and aerosol $\mathrm{NH}_{4}^{+}$ and $\mathrm{NO}_{3}^{-}$is given in Trebs et al. $(2004,2005)$.

Despite intensive biomass burning activity during the dry season, NO mixing ratios were very low (Fig. 2d). The sharp peak between 06:00 and 09:00 LT was most likely due to rapid photolysis of accumulated nighttime $\mathrm{NO}_{2}$ shortly after sunrise, when $\mathrm{O}_{3}$ mixing ratios were still too low to re- oxidize significant amounts of NO (see Fig. 2e, f), but may also be partially attributed to rapid $\mathrm{HONO}$ photolysis. $\mathrm{NO}_{2}$ was the most abundant $\mathrm{N}$-containing trace gas during all three seasons and reached an average mixing ratio of $\sim 5 \mathrm{ppb}$ during the dry season. $\mathrm{NO}_{2}$ featured a pronounced diel cycle with nighttime mixing ratios two times higher than during daytime (Fig. 2e). Apparently, $\mathrm{NO}_{2}$ was accumulated in a shallow nocturnal boundary layer of high thermodynamic stability due to: (i.) the low water-solubility of $\mathrm{NO}_{2}$ and consequently its low affinity to be taken up by epicuticular water films and (ii.) chemical production through reaction of 


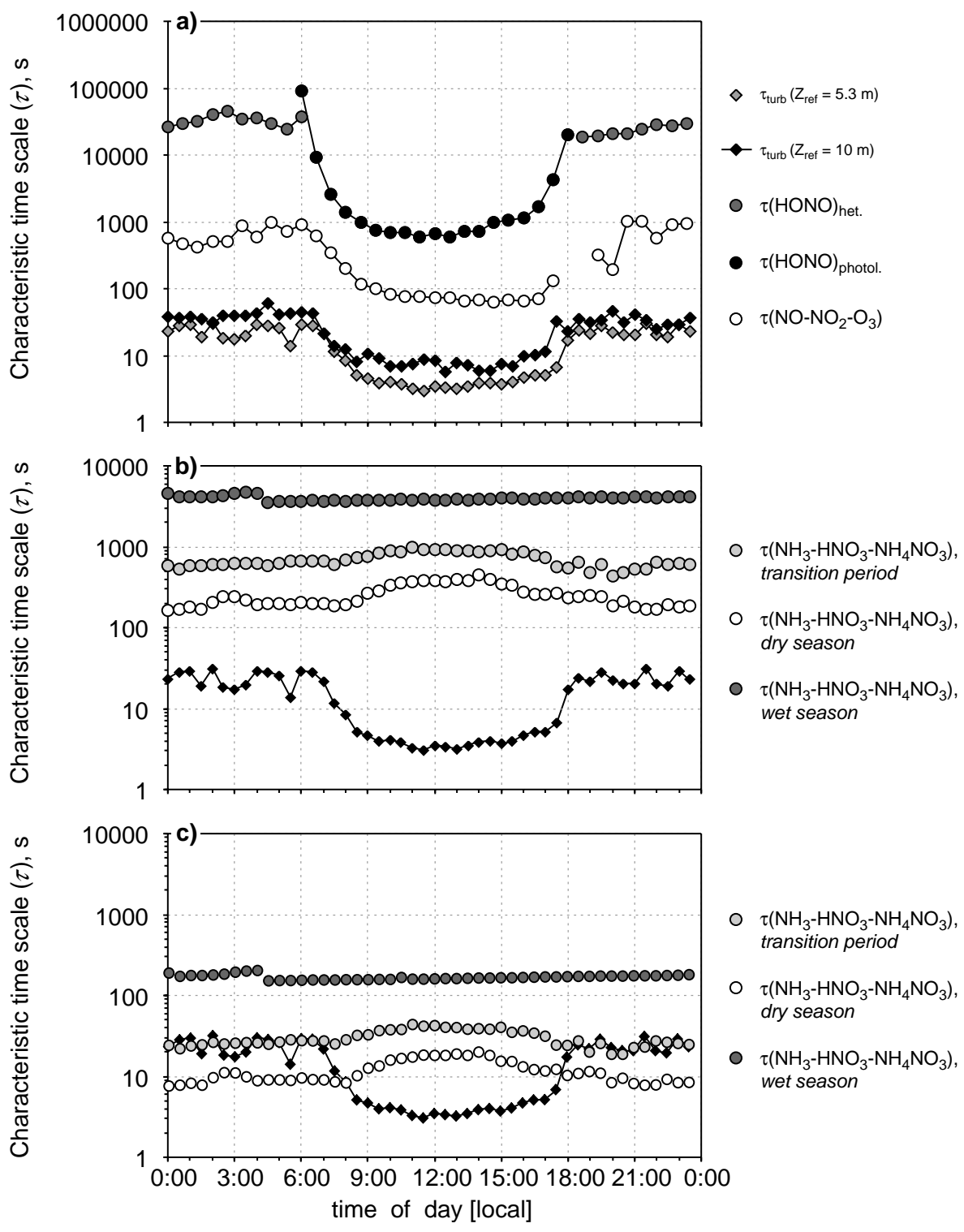

Fig. 3. Diel variation of characteristic turbulent time scale $\tau_{\text {turb }}$ for the reference heights $z_{\text {ref }}=10 \mathrm{~m}$ and $z_{\text {ref }}=5.3 \mathrm{~m}$ in comparison to (a) chemical time scale of the NO- $\mathrm{NO}_{2}-\mathrm{O}_{3}$ triad $\left(\tau\left(\mathrm{NO}-\mathrm{NO}_{2}-\mathrm{O}_{3}\right)\right)$, daytime $\mathrm{HONO}$ photolysis $(\tau(\mathrm{HONO})$ photol. $)$ and heterogeneous $\mathrm{HONO}$ formation at night $\left(\tau(\mathrm{HONO})_{\text {het. }}\right.$, dry season only), (b) upper estimate of equilibration time scales for the $\mathrm{NH}_{3} / \mathrm{HNO}_{3} / \mathrm{NH}_{4} \mathrm{NO}_{3}$ system $\tau\left(\mathrm{NH}_{3}-\mathrm{HNO}_{3}-\mathrm{NH}_{4} \mathrm{NO}_{3}\right)\left(\alpha=0.1, \mathrm{PM}_{\text {inorg. }} \leq 20 \%\right)$ and (c) lower estimate of $\tau\left(\mathrm{NH}_{3}-\mathrm{HNO}_{3}-\mathrm{NH}_{4} \mathrm{NO}_{3}\right)(\alpha=1, \mathrm{PM}=100 \%)$ at FNS during LBA-SMOCC 2002. Except for $\tau(\mathrm{HONO})_{\text {het. }}$, data from all seasons were used.

$\mathrm{NO}$ with $\mathrm{O}_{3}$ in the absence of $\mathrm{NO}_{2}$ photolysis. Through the transition period until the wet season, $\mathrm{NO}_{2}$ mixing ratios declined by a factor of four. $\mathrm{O}_{3}$ mixing ratios exhibited a typical diel variation, which mirrors that of $\mathrm{NO}_{2}$ (high values during daytime and lower values during the night; Fig. 2f). This was mainly caused by (i.) photochemical daytime production, (ii.) convective mixing within the boundary layer and from the free troposphere during daytime and (iii.) dry deposition and reaction with NO in a thermally stable stratified nocturnal boundary layer.

\subsection{Characteristic timescales}

Characteristic turbulent time scales $\left(\tau_{\text {turb }}\right)$ have been calculated according to Eq. (9) for $z_{\mathrm{ref}}=10 \mathrm{~m}\left(\mathrm{NO}_{\mathrm{x}} / \mathrm{O}_{3}\right.$ measurements) and for $z_{\text {ref }}=5.3 \mathrm{~m}$ (WAD/SJAC measurements) (cf. Table 1). To calculate the characteristic time scale for heterogeneous nighttime HONO buildup $\left(\tau(\mathrm{HONO})_{\text {het. }}\right)$ (Fig. 3a), only dry season nighttime HONO production rates $\left(P_{\mathrm{HONO}}\right)$ were considered. For the transition period and the wet season $P_{\text {HONO }}$ could not be determined since the HONO diel variation was substantially reduced (cf. Trebs et 
al., 2004). In contrast to other studies (e.g., Alicke et al., 2003; Harrison and Kitto, 1994; Lammel and Cape, 1996), our measurements revealed a relatively small average value of $P_{\mathrm{HONO}}=0.04 \mathrm{ppb} \mathrm{h}^{-1}$. Figure 3 a shows that $\tau_{\text {turb }}$ was at least two orders of magnitude smaller than $\tau(\mathrm{HONO})_{\text {photol. }}$ and $\tau(\mathrm{HONO})_{\text {het. }}$, resulting in $D_{r} \ll 0.1$. Considering the chemical time scale of the $\mathrm{NO}-\mathrm{NO}_{2}-\mathrm{O}_{3}$ triad $\tau\left(\mathrm{NO}-\mathrm{NO}_{2}-\mathrm{O}_{3}\right)$ (Fig. 3a), largest $D_{r}$ values are found between 17:00 LT and 20:00 LT, exceeding a value of $0.2\left(z_{\mathrm{ref}}=10 \mathrm{~m}\right)$. However, during all other periods $D_{r}$ for the NO- $\mathrm{NO}_{2}-\mathrm{O}_{3}$ triad ranged between 0.05 and 0.1 . Therefore, we conclude that the application of Eqs. (1) and (4) to calculate surface-atmosphere exchange fluxes of $\mathrm{NO}_{2}$ and $\mathrm{HONO}$ are justified, since chemical transformations are too slow to affect the vertical constancy of turbulent fluxes.

The estimation of the equilibration time scale $\tau\left(\mathrm{NH}_{3}-\right.$ $\mathrm{HNO}_{3}-\mathrm{NH}_{4} \mathrm{NO}_{3}$ ) was performed by integrating over the measured particle size distribution according to Eq. (10), whereby two different cases were considered. Case 1 is an upper estimate (Fig. 3b), using an accommodation coefficient $\alpha=0.1$ (Wexler and Seinfeld, 1992) and taking into account only the inorganic water-soluble aerosol fraction $(\leq 20 \%$ of $\mathrm{PM}_{\text {tot }}$ ) (cf. Trebs et al., 2005). Case 2, the lower estimate (Fig. 3c), was calculated using $\alpha=1$ and assuming that the entire aerosol mass (water-soluble and non-soluble species) are available to equilibrate. As shown in Fig. $3 b, c \tau\left(\mathrm{NH}_{3}-\right.$ $\mathrm{HNO}_{3}-\mathrm{NH}_{4} \mathrm{NO}_{3}$ ) increased substantially from the dry season through the transition period to the wet season. This is obviously caused by much higher particle number concentrations measured during the dry season when biomass burning took place. For case 1 (upper estimate) (Fig. 3b), $D_{r}$ for the $\mathrm{NH}_{3}-\mathrm{HNO}_{3}-\mathrm{NH}_{4} \mathrm{NO}_{3}$ triad during the dry season ranges from 0.1 to 0.17 at nighttime and is significantly smaller than 0.1 during the day. During the transition period and wet season, $D_{r}$ for the $\mathrm{NH}_{3}-\mathrm{HNO}_{3}-\mathrm{NH}_{4} \mathrm{NO}_{3}$ triad is always significantly smaller than 0.1 (Fig. 3b). However, for case 2 (lower estimate) (Fig. 3c) nighttime $D_{r}$ substantially exceeds a critical value of 0.1 during the dry season and the transition period.

To verify the theoretically derived values, results from a laboratory study will be discussed briefly. Condensation and evaporation of $\mathrm{NH}_{3}$ and $\mathrm{HNO}_{3}$ to/from particles have been investigated under controlled laboratory conditions. Particles were collected during field campaigns in 1991 (Brunnemann et al., 1996; Seidl et al., 1996) and 1993/1994 in the eastern part of Germany (Melpitz). The chemical aerosol composition was dominated by $\left(\mathrm{NH}_{4}\right)_{2} \mathrm{SO}_{4}, \mathrm{NaCl}$ and soot and is comparable to that described in Brunnemann et al. (1996) and Seidl et al. (1996). More than $90 \%$ of the $\mathrm{NH}_{4} \mathrm{NO}_{3}$ mass was found in the accumulation mode $\left(D_{p} \leq 1 \mu \mathrm{m}\right)$. Aerosol samples were exposed to temperature step changes of 1 to $20 \mathrm{~K}$ above $278 \mathrm{~K}$, which simulates a moderate diel cycle. $R H$ was held constant for these cases. A second set of experiments was performed where $R H$ was varied between 30 and $96 \%$ at constant temperature. In both cases non-volatile
Table 3. Ranges of daytime and nighttime surface resistances $R_{C}$ for $\mathrm{HNO}_{3}$ and $\mathrm{NO}_{2}$ used to estimate flux scenarios at FNS during LBA-SMOCC 2002.

\begin{tabular}{llcc}
\hline Scenario & $\begin{array}{c}R_{c}\left(\mathrm{HNO}_{3}\right) \\
{\left[\mathrm{s} \mathrm{m}^{-1}\right]}\end{array}$ & $\begin{array}{c}R_{c}\left(\mathrm{NO}_{2}\right) \\
{\left[\mathrm{s} \mathrm{m}^{-1}\right]}\end{array}$ \\
\hline Day & high flux & 1 & 75 \\
\multirow{2}{*}{ Night } & low flux & 50 & 550 \\
& high flux & 1 & 80 \\
& low flux & 15 & 435 \\
\hline
\end{tabular}

$\mathrm{SO}_{4}^{2-}, \mathrm{Na}^{+}$and $\mathrm{K}^{+}$were considered as reference for the relative change of $\mathrm{NO}_{3}^{-}$and $\mathrm{NH}_{4}^{+}$while changing thermodynamic conditions. The mass loss of ammonium nitrate was recorded as a function of time for particles with a radius of $\mathrm{r}<0.8 \mu \mathrm{m}$ and $\mathrm{r}>1.6 \mu \mathrm{m}$. Timescales $\tau\left(\mathrm{NH}_{3}-\mathrm{HNO}_{3}-\right.$ $\mathrm{NH}_{4} \mathrm{NO}_{3}$ ) were calculated using the algorithm proposed by (i.) Kramm and Dlugi (1994) and (ii.) Meng and Seinfeld (1996), resulting in $\tau\left(\mathrm{NH}_{3}-\mathrm{HNO}_{3}-\mathrm{NH}_{4} \mathrm{NO}_{3}\right)=100-500 \mathrm{~s}$ for fine mode particles and $\geq 880 \mathrm{~s}$ for coarse mode particles. These values are comparable to characteristic times reported by Harrison et al. (1990) and Meng and Seinfeld (1996) and are in strong favor of our case 1 (upper estimate, Fig. 3b), which implies that the equilibration time scale was always much larger than that of turbulent transport. Nevertheless, it should be noted that the influence of the large soluble organic aerosol fraction typical for the Amazon Basin (cf. Trebs et al., 2005) on gas/aerosol partitioning processes is not exactly known. Taking into account the potential role of WSOC in enhancing aerosol water uptake and subsequently the uptake of gaseous species, equilibration time scales may be equal or even faster than turbulent transport (cf. Fig. 3c).

\subsection{The inferential approach: selection of input parameters}

Some surface parameters required for the inferential method to estimate of surface-atmosphere exchange fluxes for trace gases (Eqs. 1-7) could not be directly derived from the results of our field measurements. Thus, lower and upper scenarios were estimated (except for HONO; see below), comprising a certain range of surface-atmosphere exchange fluxes. These scenarios were obtained by varying surface parameters over a selected range based on results from studies in temperate latitudes. Note that for all parameters and quantities presented, values indicated as "low" and values indicated as "high" correspond to the estimated lower and upper fluxes, respectively.

Surface resistances $R_{c}\left(\mathrm{HNO}_{3}\right)$ and $R_{c}\left(\mathrm{NO}_{2}\right): R_{c}\left(\mathrm{HNO}_{3}\right)$ was found to be zero in many studies (e.g., Dollard et al., 1987; Huebert and Robert, 1985). Very recently, Nemitz et al. (2004a) showed that non-zero, however, relatively small $R_{c}\left(\mathrm{HNO}_{3}\right)$ may exist $\left(R_{c}=15-95 \mathrm{~s} \mathrm{~m}^{-1}\right)$. The ranges 

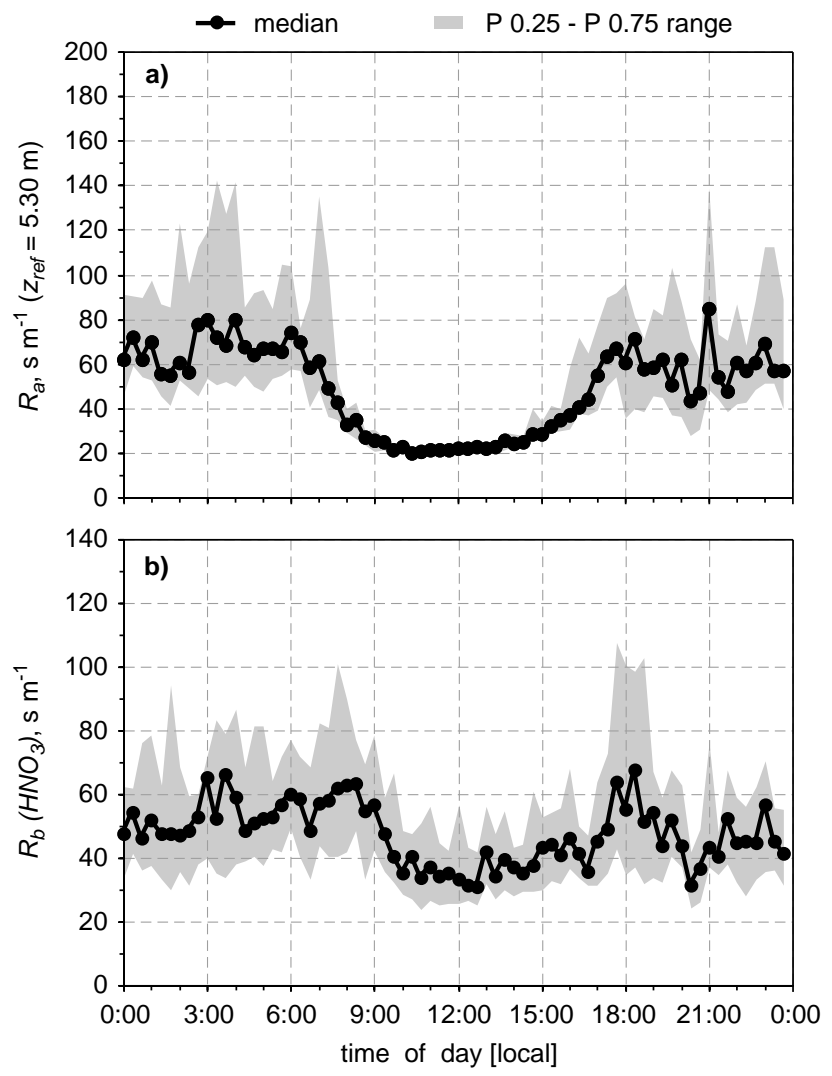

Fig. 4. Diel variations of (a) turbulent resistance $\left(R_{a}\right)$ and (b) quasi-laminar boundary layer resistance $\left(R_{b}\right)$ exemplary for $\mathrm{HNO}_{3}$ at FNS during LBA-SMOCC 2002. Symbols and grey shading represent medians and interquartile ranges ( 0.25 to 0.75 percentiles), respectively. Data from all seasons were used.

of $R_{C}\left(\mathrm{HNO}_{3}\right)$ used to estimate lower and upper surfaceatmosphere exchange fluxes are given in Table 3 . The surface uptake of $\mathrm{HNO}_{3}$ is considered to be enhanced by the presence of epicuticular water films under the humid conditions at the site (lower $R_{c}$ values were chosen for nighttime). $R_{c}\left(\mathrm{NO}_{2}\right)$ has been determined previously at the FNS site by Kirkman et al. (2002), hence the maximal and minimal diel variations of $R_{c}\left(\mathrm{NO}_{2}\right)$ were taken directly from Kirkman et al. (2002) to estimate lower and upper surface-atmosphere exchange, respectively. Corresponding averages of maximal and minimal $R_{c}\left(\mathrm{NO}_{2}\right)$ values are given in Table 3.

Stomatal resistance $R_{S}\left(\mathrm{NH}_{3}\right)$ and charging resistance $R_{d}\left(\mathrm{NH}_{3}\right): R_{s}\left(\mathrm{NH}_{3}\right)$ is not known for Brachiaria brizantha grass species, therefore the diffusion of $\mathrm{H}_{2} \mathrm{O}$ through plant stomata is used for the calculation of upper and lower flux estimates. Thus, $R_{S}\left(\mathrm{NH}_{3}\right)$ is estimated according to Nemitz et al. (2004a) using the measured latent heat flux $L E$. This approach is only valid for relatively dry daytime conditions (10:00-18:00 LT) and in the absence of precipitation. The transfer of $\mathrm{H}_{2} \mathrm{O}$ through plant stomata during daytime represents an upper boundary for trace gas stomatal exchange.
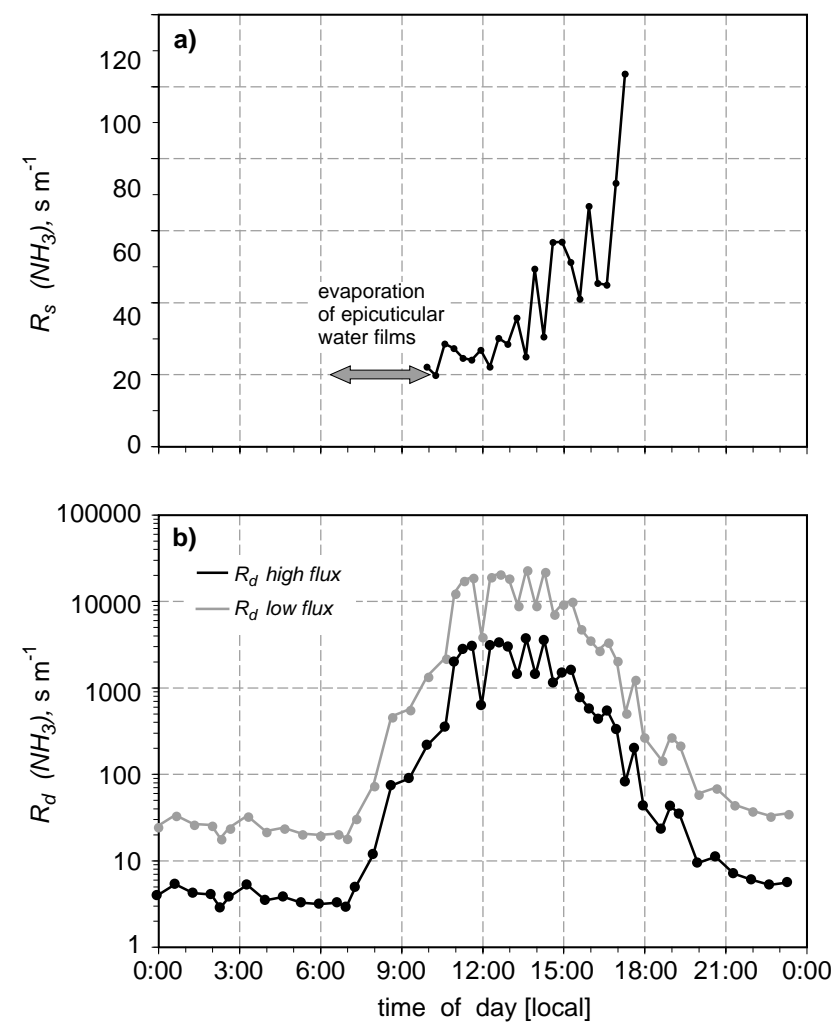

Fig. 5. Median diel variations of estimated (a) $\mathrm{NH}_{3}$ stomatal resistance $R_{S}\left(\mathrm{NH}_{3}\right)$ during daytime, using the measured latent heat flux $L E\left(R_{S}\left(\mathrm{NH}_{3}\right)\right.$ was set to $1000 \mathrm{~m} \mathrm{~s}^{-1}$ for nighttime periods) and (b) lower (high flux) and upper (low flux) $\mathrm{NH}_{3}$ charging resistance of the surface water layer $\left(R_{d}\left(\mathrm{NH}_{3}\right)\right)$ at FNS during LBA-SMOCC 2002. Data from all seasons were used.

Since stomata are thought to be closed during nighttime, $R_{S}\left(\mathrm{NH}_{3}\right)$ is set to $1000 \mathrm{~s} \mathrm{~m}^{-1}$ for nighttime periods. The calculation of $R_{d}\left(\mathrm{NH}_{3}\right)$ is performed in accordance with Sutton et al. (1998).

Compensation point concentration $X_{c}(H O N O)$ : $\mathrm{Up}$ to date, only two studies provide an estimate for $X_{c}(\mathrm{HONO})$ (Harrison and Kitto, 1994; Stutz et al., 2002). Here, the relationship $X_{c}(\mathrm{HONO})=0.03 \cdot X\left(\mathrm{NO}_{2}, z_{\text {ref }}\right)$ was used, which was found for grassland in the recent study by Stutz et al. (2002). This corresponds on average to $X_{c}(\mathrm{HONO})=85 \mathrm{ppt}$ at the FNS site.

Apoplastic $\left[\mathrm{NH}_{4}^{+}\right] /\left[\mathrm{H}^{+}\right]$ratio $\Gamma$ and epicuticular $\mathrm{pH}$ : For $\Gamma$, we have chosen values of 100 (lower estimate) and 200 (upper estimate), which range at the lower end of data reported for grass in the literature (Loubet et al., 2002; Spindler et al., 2001; van Hove et al., 2002). This may be justified by the poor soil N status at FNS (Kirkman et al., 2002), because $\mathrm{N}$ absorbed by the root medium strongly affects the leaf tissue $\mathrm{NH}_{4}^{+}$concentration (Schjoerring et al., 1998a). The capacitance of the epicuticular water film is a function of the pH (see Sect. 3.1, Sutton et al., 1998), that is predominantly 
acidic (Flechard et al., 1999) and is taken as 4.5 (lower estimate) and as 4.0 (upper estimate) (cf. Sutton et al., 1998).

$\mathrm{NH}_{3}$ flux from cattle excreta $\mathrm{F}\left(\mathrm{NH}_{3}\right)_{e}$ : In order to estimate the contribution of cattle excreta to the net $\mathrm{NH}_{3}$ flux, we considered results of Boddey et al. (2004), who investigated the cycling of $\mathrm{N}$ in Brachiaria pastures in the south of the Brazilian province Bahia. According to their results, Bos indicus cattle excreted $37 \mathrm{kgN}$ animal ${ }^{-1} \mathrm{yr}^{-1}$ in manure and $49 \mathrm{kgN}$ animal ${ }^{-1} \mathrm{yr}^{-1}$ in urine when the pastures were stocked with two animals per hectare. The stocking rate at FNS was one animal per hectare. About $8 \%$ of the excreted $\mathrm{N}$ may be released as $\mathrm{NH}_{3}$ (A. F. Bouwman, personal communication, 2004). Hence, the average $F\left(\mathrm{NH}_{3}\right)_{e}$ is estimated to be $\sim 10 \mathrm{ngN} \mathrm{m}^{-2} \mathrm{~s}^{-1}$, which is applied for the entire measurement period (Eqs. 5, 6).

4.5 Resistances, $\mathrm{NH}_{3}$ canopy compensation point, transferand deposition velocities

The turbulent resistance $R_{a}$ and the quasi-laminar boundary layer resistance $R_{b}$ (Fig. $\left.4 a, b\right)$ : These resistances feature a typical diel variation with lowest values during daytime $\left(R_{a}\right.$ $\left.(5.3 \mathrm{~m})=20 \mathrm{~s} \mathrm{~m}^{-1}, R_{b}=30 \mathrm{~s} \mathrm{~m}^{-1}\right)$, because of strong turbulent mixing within the surface layer, and higher values during nighttime $\left(R_{a}(5.3 \mathrm{~m})=70 \mathrm{~s} \mathrm{~m}^{-1}\right.$ and $\left.R_{b}=50 \mathrm{~s} \mathrm{~m}^{-1}\right)$.

The stomatal resistance $\mathrm{R}_{S}\left(\mathrm{NH}_{3}\right)$ and the charging resistance $\mathrm{R}_{d}\left(\mathrm{NH}_{3}\right)$ (Fig. $5 a, b$ ): The median diel cycle of $R_{S}\left(\mathrm{NH}_{3}\right)$ estimated from $L E$ during daytime (Fig. 5a) reaches very low values, falling below $50 \mathrm{~s} \mathrm{~m}^{-1}$ between 10:00 and 14:00 LT. In the afternoon $R_{s}\left(\mathrm{NH}_{3}\right)$ increases and attains values $>100 \mathrm{~s} \mathrm{~m}^{-1}$ after 17:00 LT. $R_{S}\left(\mathrm{NH}_{3}\right)$ is set to a value of $1000 \mathrm{~s} \mathrm{~m}^{-1}$ for nighttime periods (see above; not shown). The simulated $R_{d}\left(\mathrm{NH}_{3}\right)$ (Fig. $5 \mathrm{~b}$ ) is very high during daytime $\left(>1000 \mathrm{~s} \mathrm{~m}^{-1}\right)$ and remains below $100 \mathrm{~s} \mathrm{~m}^{-1}$ at night. This is obviously due to the fact that grass leaves became dry during sunlight hours (see below, Fig. 6), resulting in a very low capacity of the foliar cuticle to adsorb $\mathrm{NH}_{3}$.

The $\mathrm{NH}_{3}$ canopy compensation point concentration $X_{c}\left(\mathrm{NH}_{3}\right)$ (Fig. 6): The $X_{c}\left(\mathrm{NH}_{3}\right)$ scenario for the dry season calculated according to Eq. (6) lies well within the range of values determined for grassland in other studies (Hesterberg et al., 1996; Meixner et al., 1996; Spindler et al., 2001; Sutton et al., 2001) and is a strong function of surface temperature (cf. Eq. 6, 7). $X_{c}\left(\mathrm{NH}_{3}\right)$ is predicted to be particularly high at daytime, although low values of $\Gamma$ were used to run the model. This is caused by prevailing high surface temperatures at the FNS pasture site $\left(35-40^{\circ} \mathrm{C}\right.$ at daytime and 20 $25^{\circ} \mathrm{C}$ at night during the dry season). $\mathrm{NH}_{3}$ deposits and dissolves in epicuticular water films at high $R H s$ during nighttime. After sunrise the increasing surface temperature causes the $\mathrm{NH}_{3}$ partial pressure above the epicuticular solution to increase in accordance to Henry's law. Hence, $X_{d}\left(\mathrm{NH}_{3}\right)$ increases, which in turn results in higher $X_{c}\left(\mathrm{NH}_{3}\right)$ values. This is visible in Fig. 6 as a distinctive peak of $X_{c}\left(\mathrm{NH}_{3}\right)$ after sunrise between 08:00 and 09:00 LT. Once most of the

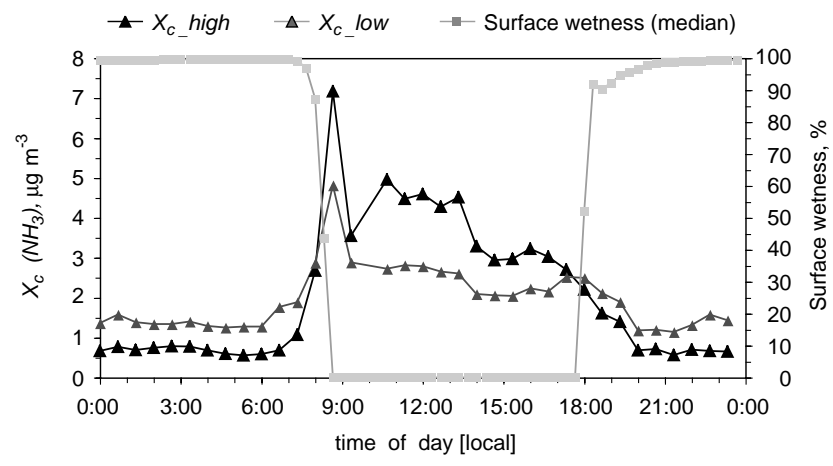

Fig. 6. Median diel variation of the simulated lower (low flux) and upper (high flux) $\mathrm{NH}_{3}$ canopy compensation point $X_{c}\left(\mathrm{NH}_{3}\right)$, and the median diel variation of the measured surface wetness, shown exemplarily for a period during the dry season (12-23 September) at FNS during LBA-SMOCC 2002. For details about low and high estimates, see text.

epicuticular $\mathrm{NH}_{4}^{+}$has evaporated, $X_{c}\left(\mathrm{NH}_{3}\right)$ subsequently decreases (after 09:00 LT). Lower surface temperatures during the transition period and the wet season have caused lower estimates of $X_{c}\left(\mathrm{NH}_{3}\right)\left(0.3-1 \mu \mathrm{g} \mathrm{m}^{-3}\right.$ during nighttime and $1-4 \mu \mathrm{g} \mathrm{m}^{-3}$ during daytime).

Transfer- and deposition velocities $V_{\mathrm{tr} .}\left(\mathrm{NH}_{3}\right)$, $V_{\text {tr. }}(\mathrm{HONO}), \quad V_{d}\left(\mathrm{HNO}_{3}\right), \quad V_{d}\left(\mathrm{NO}_{2}\right) \quad$ (Fig. $\left.\quad 7 a-d\right)$ and $V_{p}$ (aerosol) (Fig. 8): For compounds featuring a bidirectional surface exchange the concept of a dry deposition velocity $V_{d}=\left(R_{a}+R_{b}+R_{c}\right)^{-1}$ (see Eq. 1) is no longer useful (e.g., Kramm and Dlugi, 1994). Thus, for bi-directional $\mathrm{NH}_{3}$ and HONO surface-atmosphere exchange the term transfer velocity $V_{\text {tr. }}=-\operatorname{sgn}\left(X_{c}-X\left(z_{\text {ref }}\right)\right) /\left(R_{a}+R_{b}\right)$ (see Eqs. 4,5$)$ will be used henceforth.

The estimated median diel variation of $V_{\text {tr. }}\left(\mathrm{NH}_{3}\right)$ (Fig. 7a) indicates net deposition ( $=$ downward flux) at nighttime $\left(V_{\text {tr. }}\left(\mathrm{NH}_{3}\right)>0\right)$ and net emission (= upward flux) $\left(V_{\mathrm{tr}}\left(\mathrm{NH}_{3}\right)<0\right)$ during the day. Typically, $V_{\mathrm{tr}}\left(\mathrm{NH}_{3}\right)$ is predicted to range between $-2.6 \mathrm{~cm} \mathrm{~s}^{-1}$ during the day and $1.5 \mathrm{~cm} \mathrm{~s}^{-1}$ at nighttime. For cases of $\mathrm{NH}_{3}$ deposition, $V_{\text {tr. }}\left(\mathrm{NH}_{3}\right)$ is in good agreement with values of $0.1-2 \mathrm{~cm}$ $\mathrm{s}^{-1}$ observed by Erisman and Wyers (1993), Hesterberg et al. (1996), Nemitz et al. (2004a), Phillips et al. (2004) and Rattray and Sievering (2001). For cases of $\mathrm{NH}_{3}$ emission, $V_{\text {tr. }}\left(\mathrm{NH}_{3}\right)$ agrees well with values reported by e.g., Nemitz et al. (2004a). The application of the dynamic resistance model from Sutton et al. (1998), which uses nonzero $X_{c}\left(\mathrm{NH}_{3}\right)$ values and takes into account that deposited $\mathrm{NH}_{3}$ may (re-)evaporate from surfaces, represents a rather conservative $\mathrm{N}$ deposition estimate (lower boundary). Since $X_{c}\left(\mathrm{NH}_{3}\right)$ was assumed to be zero in several studies (Goulding et al., 1998; Russell et al., 2003; Singh et al., 2001; Tarnay et al., 2001), which implies that $\mathrm{NH}_{3}$ is persistently net deposited to the surface (see Eq. 1), we have complemented the upper and lower bi-directional flux scenarios by 

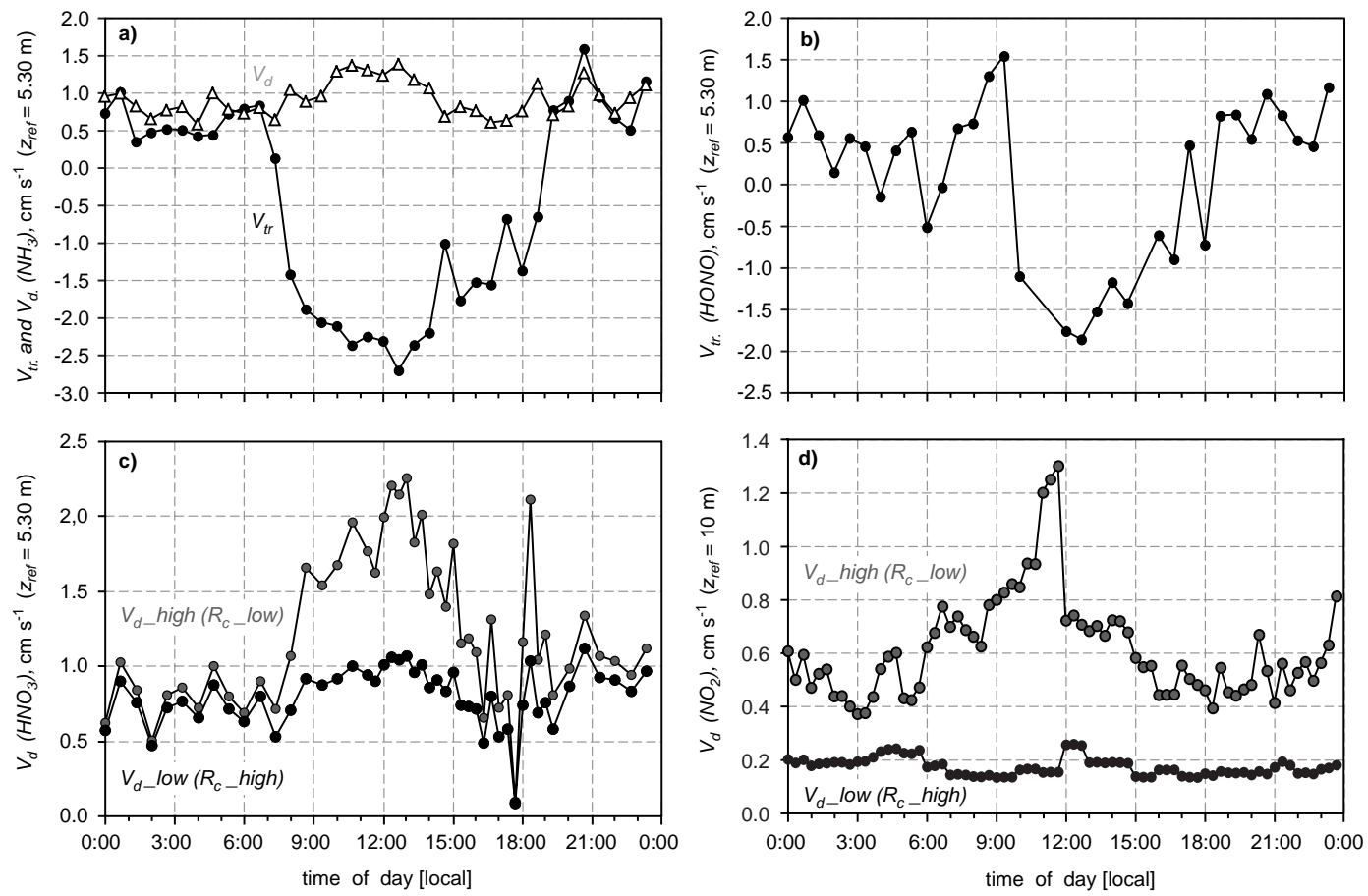

Fig. 7. Median diel variation of estimated transfer- $\left(V_{\text {tr. }}\right)$ and deposition velocities $\left(V_{d}\right)$ for $(\mathbf{a}) \mathrm{NH}_{3}\left(z_{\text {ref }}=5.3 \mathrm{~m}\right)(\mathbf{b}) \mathrm{HONO}\left(z_{\text {ref }}=5.3 \mathrm{~m}\right)$, (c) $\mathrm{HNO}_{3}\left(z_{\mathrm{ref}}=5.3 \mathrm{~m}\right)$ and $(\mathbf{d}) \mathrm{NO}_{2}\left(z_{\mathrm{ref}}=10 \mathrm{~m}\right)$ at FNS during LBA-SMOCC 2002. The bi-directional $\mathrm{NH}_{3}$ flux was complemented by a "deposition only scenario" (cf. $V_{d}$ in a). Data from all seasons were used, except for $V_{\text {tr. }}$ (HONO), which only represents results from the dry season, since negligible small upward HONO fluxes were predicted during transition period and wet season.

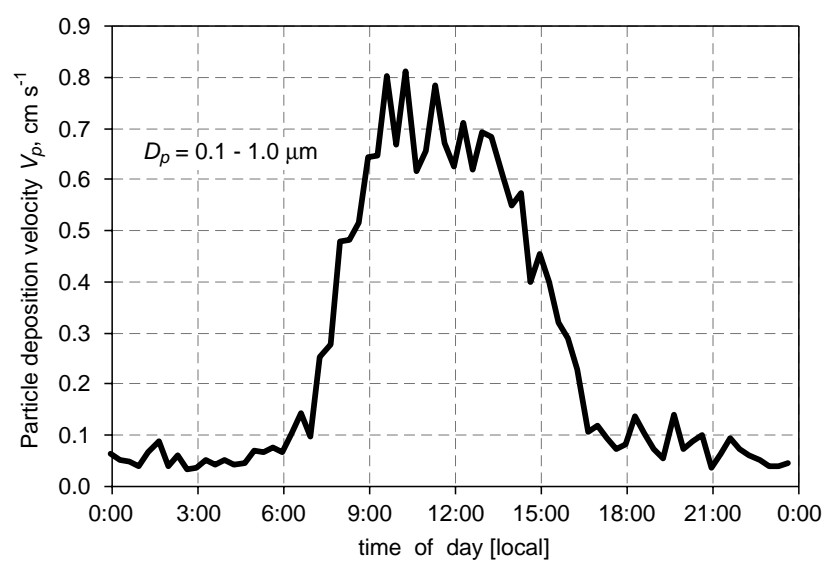

Fig. 8. Median diel course of the particle deposition velocity $V_{p}$ $\left(z_{\text {ref }}=5.3 \mathrm{~m}\right)$ using the empirical parameterization derived by Wesely et al. (1985) for aerosol particles with $D_{p}=0.1-1 \mu \mathrm{m}$ at FNS during LBA-SMOCC 2002.

additionally calculating a "deposition only" scenario according to Eq. (1) ( $V_{d}$ in Fig. 7a), where $R_{c}\left(\mathrm{NH}_{3}\right)$ was calculated from the parallel resistances $R_{S}\left(\mathrm{NH}_{3}\right)$ and $R_{d}\left(\mathrm{NH}_{3}\right)$ (see Fig. 5a, b). Assuming $\mathrm{NH}_{3}$ to be net deposited to the pasture site results in $V_{d}=0.5-1.5 \mathrm{~cm} \mathrm{~s}^{-1}$ (Fig. 7a).
The estimated median diel variation of $V_{\text {tr. }}$ (HONO) (Fig. 7b, dry season only) similarly shows net deposition at night and net emission during the day, with $V_{\text {tr. }}$ (HONO) ranging from $-1.7 \mathrm{~cm} \mathrm{~s}^{-1}$ to $1.5 \mathrm{~cm} \mathrm{~s}^{-1}$. For cases of HONO deposition, these values are comparable to $V_{\text {tr. }}(\mathrm{HONO})$ of 0 $1.7 \mathrm{~cm} \mathrm{~s}^{-1}$ reported by Harrison and Kitto (1994) and Stutz et al. (2002).

The estimates of $V_{d}\left(\mathrm{HNO}_{3}\right)$ shown in Fig. 7c, reveal maximal median values of $2.3 \mathrm{~cm} \mathrm{~s}^{-1}$ at around 13:00 LT when $R_{c}\left(\mathrm{HNO}_{3}\right)=1 \mathrm{~s} \mathrm{~m}^{-1}$ is applied (see Table 3, upper flux estimate), coinciding with the period of highest turbulence. The lower estimate, when $R_{c}\left(\mathrm{HNO}_{3}\right)$ is taken as $50 \mathrm{~s} \mathrm{~m}^{-1}$ during daytime and as $15 \mathrm{~s} \mathrm{~m}^{-1}$ during nighttime (see Table 3 ), results in median $V_{d}\left(\mathrm{HNO}_{3}\right)$ values nearly equal during day and night $\left(\leq 1.1 \mathrm{~cm} \mathrm{~s}^{-1}\right)$, which is attributed to the compensating effect of lower surface uptake and low turbulent exchange during nighttime. Although $V_{d}\left(\mathrm{HNO}_{3}\right)$ was found to be higher (3-4 $\left.\mathrm{cm} \mathrm{s}^{-1}\right)$ in other studies (e.g., Erisman et al., 1988), our values are still in reasonable agreement with deposition velocities determined by Dollard et al. (1987), Müller et al. (1993), Nemitz et al. (2004a) and Rattray and Sievering (2001) for vegetative canopies similar to that at FNS. It should be noted here that for a compound that is exchanged with a very small $R_{c}$ (as in the case for $\mathrm{HNO}_{3}$ ), $V_{d}$ is mainly dependent on $R_{a}+R_{b}$. Thus, this comparison reflects largely the differences in turbulence and surface roughness. 

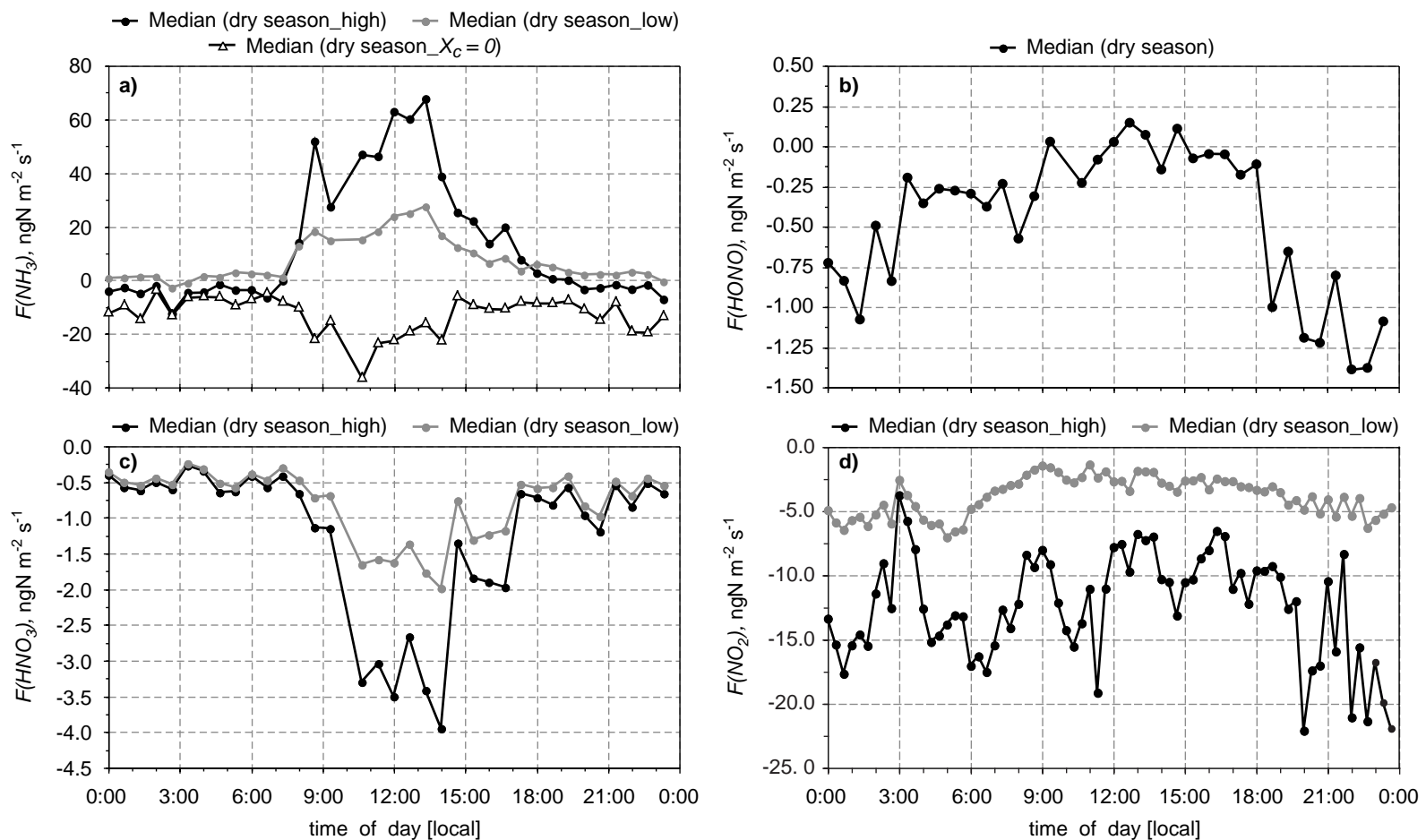

Fig. 9. Median diel courses of estimated lower (low) and upper (high) surface-atmosphere exchange fluxes for: $(\mathbf{a}) \mathrm{NH}_{3}\left(z_{\mathrm{ref}}=5.3 \mathrm{~m}\right)$ (b) HONO $\left(z_{\mathrm{ref}}=5.3 \mathrm{~m}\right)$, (c) $\mathrm{HNO}_{3}\left(z_{\mathrm{ref}}=5.3 \mathrm{~m}\right)$ and $(\mathbf{d}) \mathrm{NO}_{2}\left(z_{\mathrm{ref}}=10 \mathrm{~m}\right)$. Bi-directional $\mathrm{NH}_{3}$ flux scenarios were complemented by a "deposition only" scenario $\left(X_{c}\left(\mathrm{NH}_{3}\right)=0\right)$. Only one scenario could be calculated for HONO due to the restricted availability of input parameters (cf. Sect. 4.4). Median diel courses are presented exemplarily for a period during the dry season (12-23 September) at FNS during LBA-SMOCC 2002.

The median diel course of $V_{d}\left(\mathrm{NO}_{2}\right)$ shown in Fig. 7d exhibits maxima of $\sim 1.3 \mathrm{~cm} \mathrm{~s}^{-1}$ during daytime, while minimal values are below $0.2 \mathrm{~cm} \mathrm{~s}^{-1}$. These values compare relatively well with ranges of $V_{d}\left(\mathrm{NO}_{2}\right)$ reported by Kirkman et al. (2002). However, the dry deposition of $\mathrm{NO}_{2}$ is thought to be mainly featured by uptake through plant stomata, which would imply that much higher dry deposition velocities (and hence much lower $R_{c}$ ) occur during daytime. As stated by Kirkman et al. (2002), measured day- and nighttime $R_{c}$ values for $\mathrm{NO}_{2}$ at FNS were similar (see also Table 3), which was assumed to be mainly a result of stomatal closure due to high water vapor pressure deficit at lower $R H$ 's during daytime.

Deposition velocities $V_{p}\left(z_{\text {ref }}=5.3 \mathrm{~m}\right)$ predicted for particles (Fig. 8) are estimated to be highest during daytime $\left(\leq 0.8 \mathrm{~cm} \mathrm{~s}^{-1}\right)$ in accordance with higher values of $u_{*}$. During nighttime, $V_{p}$ generally remains below $0.1 \mathrm{~cm} \mathrm{~s}^{-1}$. As previously indicated, these values are much larger than $V_{p}$ predicted by Slinn (1982) and are therefore considered as an upper estimate. It should be pointed out that aerosol water uptake at high $R H s$ and the resulting particle growth during the deposition process may enhance deposition velocities (Khlystov, 1998; Gallagher et al., 1997). In our study, this would be particularly relevant for nighttime periods when
$R H$ usually exceeded $90 \%$. However, a quantification of this effect would go beyond the scope of this work.

\subsection{Surface-atmosphere exchange fluxes}

In this section, the measured mixing ratios (Sect. 4.2), the input parameters for the inferential approach (discussed in Sect. 4.4) and the results presented in section 4.5 will be used to estimate and discuss surface-atmosphere exchange fluxes of $\mathrm{N}$-containing trace gases and aerosol particles.

Bi-directional fluxes of gaseous $\mathrm{NH}_{3}, \mathrm{~F}\left(\mathrm{NH}_{3}\right)$ (Fig. 9a): Fluxes found at locations in temperate regions with vegetative surfaces similar to the grass surface at FNS are comparable to our upper bi-directional estimate of $F\left(\mathrm{NH}_{3}\right)$ for the dry season (biomass burning) (Fig. 9a) (Erisman and Wyers, 1993; Flechard et al., 1999; Meixner et al., 1996; Spindler et al., 2001). The net emission peak between 08:00 and 09:30 LT in the upper estimate corresponds to the peak of the predicted $\mathrm{NH}_{3}$ canopy compensation point (cf. Fig. 6) and the highest observed $\mathrm{NH}_{3}$ mixing ratios (see Fig. 2a). As already mentioned above, this feature may be related to desorption of $\mathrm{NH}_{3}$ from epicuticular water films due to an increase of surface temperature after sunrise (see also Trebs et al., 2005). Relatively high median $\mathrm{NH}_{3}$ net emission fluxes (5-70 $\mathrm{ngN} \mathrm{m}^{-2} \mathrm{~s}^{-1}$, upper estimate) during daytime 


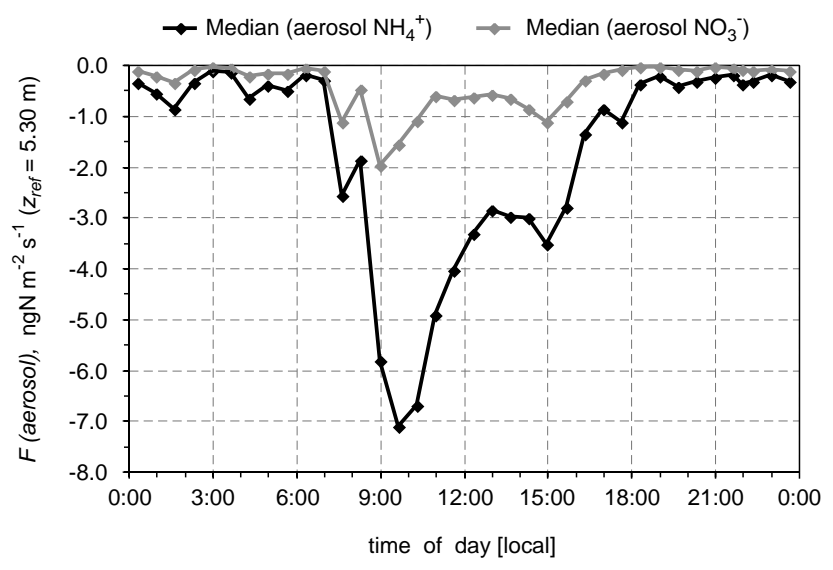

Fig. 10. Median diel courses of inferred deposition fluxes of aerosol $\mathrm{NH}_{4}^{+}$and $\mathrm{NO}_{3}^{-}$shown exemplarily for a period during the dry season (12-23 September) at FNS during LBA-SMOCC 2002.

(08:00-17:30 LT) are the result of (i.) relatively high $\mathrm{NH}_{3}$ mixing ratios (Fig. 2a), (ii.) direct $\mathrm{NH}_{3}$ emission from cattle excreta, (iii.) high surface temperatures and (iv.) corresponding high values of simulated $X_{c}\left(\mathrm{NH}_{3}\right)$ (see Fig. 6). The simulated nighttime $\mathrm{NH}_{3}$ net deposition (upper estimate) $(19: 00-06: 30 \mathrm{LT})$ is on average -2 to $-13 \mathrm{ngN} \mathrm{m}^{-2}$ $\mathrm{s}^{-1}$. The lower $\mathrm{NH}_{3}$ flux estimate shown in Fig. 9a suggests that the net exchange of $\mathrm{NH}_{3}$ may be significantly smaller when a higher epicuticular $\mathrm{pH}$ (4.5) (Sect. 4.4), a lower apoplastic $\left[\mathrm{NH}_{4}^{+}\right] /\left[\mathrm{H}^{+}\right]$ratio $\Gamma$ (Sect. 4.4) and higher $R_{d}\left(\mathrm{NH}_{3}\right)$ (Fig. 5b) are applied. The estimated $\mathrm{NH}_{3}$ net deposition for this case during nighttime is negligible and the predicted daytime $\mathrm{NH}_{3}$ net emission varies between 1 and $28 \mathrm{ngN} \mathrm{m}^{-2} \mathrm{~s}^{-1}$. During the transition period and the wet season, however, the lower $\mathrm{NH}_{3}$ flux estimate (not shown) features emission during day and night. The " $\mathrm{NH}_{3}$ deposition only" scenario $\left(X_{c}\left(\mathrm{NH}_{3}\right)=0\right.$; Fig. 9a) exhibits highest fluxes during daytime (08:00-15:00 LT), with values ranging between -20 and $-40 \mathrm{ngN} \mathrm{m}{ }^{-2} \mathrm{~s}^{-1}$. At nighttime, net deposition fluxes between -5 and $-20 \mathrm{ngN} \mathrm{m}^{-2} \mathrm{~s}^{-1}$ were estimated.

The predicted bi-directional $\mathrm{NH}_{3}$ flux scenarios are most sensitive to the $\mathrm{pH}$ of the epicuticular water film and the $\mathrm{H}^{+}$and $\mathrm{NH}_{4}^{+}$concentrations in the apoplastic fluid $(\Gamma)$. If the $\mathrm{pH}$ of the epicuticular water film were $>4.5$ and $\Gamma$ constant (100-200), the upper $\mathrm{NH}_{3}$ flux estimate would show net emission also during nighttime. On the other hand, increasing $\Gamma$ beyond a value of 200 would result in daytime $\mathrm{NH}_{3}$ net emissions significantly higher than observed in urban regions in Europe or North America.

Bi-directional fluxes of gaseous HONO, F(HONO) (Fig. 9b): The estimated median diel HONO flux during the dry season (12 to 23 September), shows a small net emission during the afternoon but net deposition of up to $-1.3 \mathrm{ngN}$ $\mathrm{m}^{-2} \mathrm{~s}^{-1}$ from 17:00-08:40 LT. We like to note, that the HONO flux scenario presented here probably reflects the
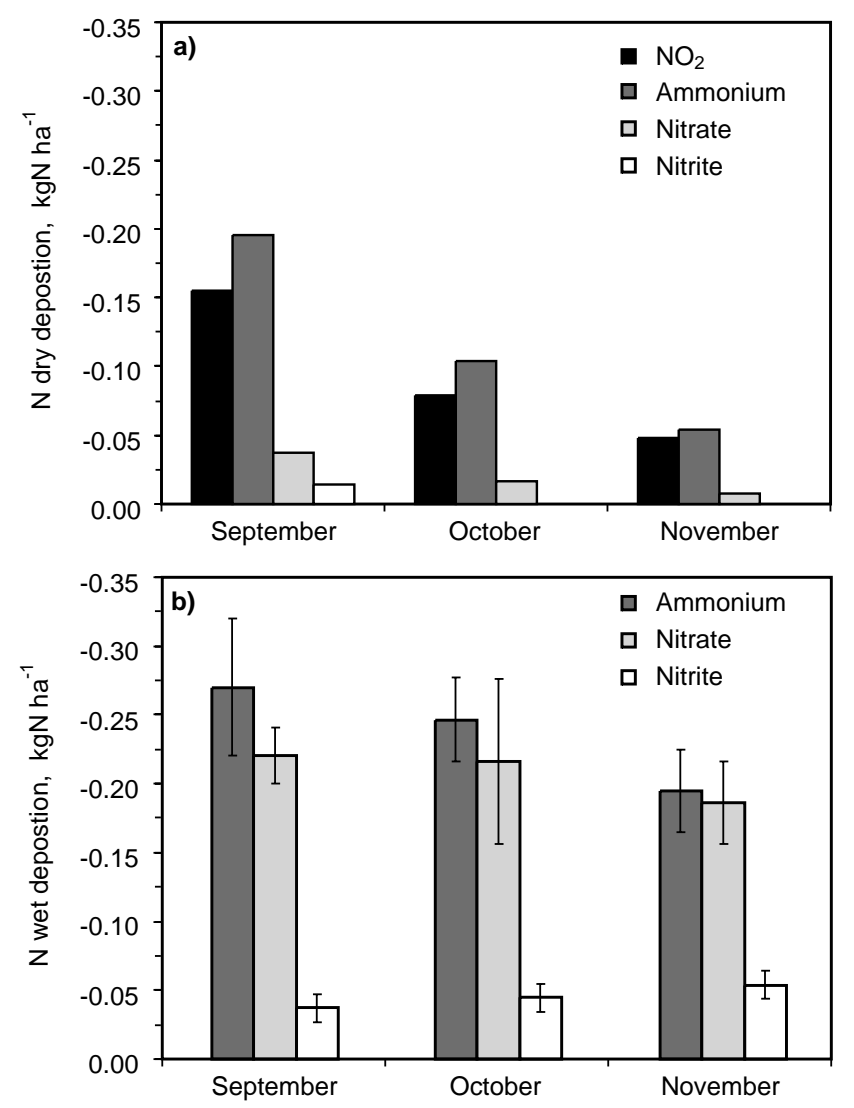

Fig. 11. Monthly estimates of (a) $\mathrm{N}$ dry deposition of $\mathrm{NO}_{2}$, total ammonium (aerosol $\mathrm{NH}_{4}^{+}+\mathrm{NH}_{3}$ ), total nitrate (aerosol $\mathrm{NO}_{3}^{-}+\mathrm{HNO}_{3}$ ) and nitrite (HONO) (averages of lower and upper flux estimates are shown, except for $\mathrm{NH}_{3}$ which represents an average of all three estimates (cf. Fig. 9a) and (b) $\mathrm{N}$ wet deposition of ammonium, nitrate and nitrite (error bars represent measurement uncertainties) for September (dry season, biomass burning), October (transition period) and November (wet season, clean conditions) at FNS during LBA-SMOCC 2002.

largest uncertainty of all flux estimates since presently neither $X_{c}(\mathrm{HONO})$, nor the exact HONO formation mechanism are well known.

Fluxes of gaseous $\mathrm{HNO}_{3}, \mathrm{~F}\left(\mathrm{HNO}_{3}\right)$ (Fig. 9c): The estimated median diel $\mathrm{HNO}_{3}$ flux scenario during the dry season is characterized by highest net deposition values from 09:00-16:30 LT ( $\sim-0.5$ to $-4 \mathrm{ngN} \mathrm{m}^{-2} \mathrm{~s}^{-1}$, upper estimate), coinciding with highest estimated deposition velocities (cf. Fig. 7c) and the maximal observed $\mathrm{HNO}_{3}$ mixing ratios (cf. Fig. 2b). Predicted nighttime $\mathrm{HNO}_{3}$ deposition fluxes are lower in accordance with lower turbulence (lower $V_{d}$ ) and lower $\mathrm{HNO}_{3}$ mixing ratios. The higher values of $R_{c}\left(\mathrm{HNO}_{3}\right)$ applied for the lower flux estimate (Table 3$)$ result in daytime net deposition fluxes that are a factor of two lower than for the upper flux estimate.

Fluxes of gaseous $\mathrm{NO}_{2}, \mathrm{~F}\left(\mathrm{NO}_{2}\right)$ (Fig. 9d): The diel course of the estimated $\mathrm{NO}_{2}$ flux scenario (dry season) is always 
a) dry (biomass burning) season

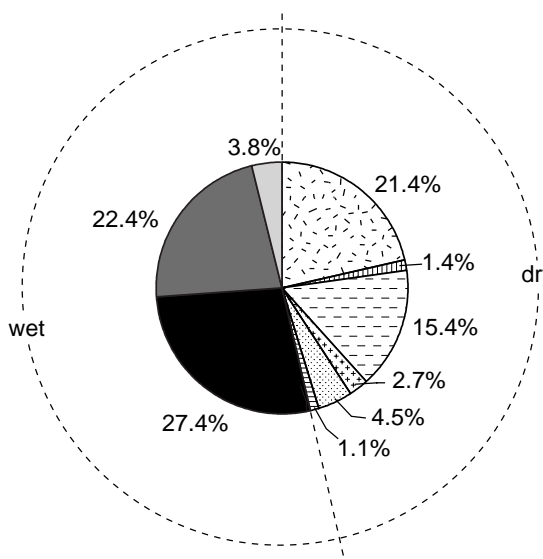

c) wet season

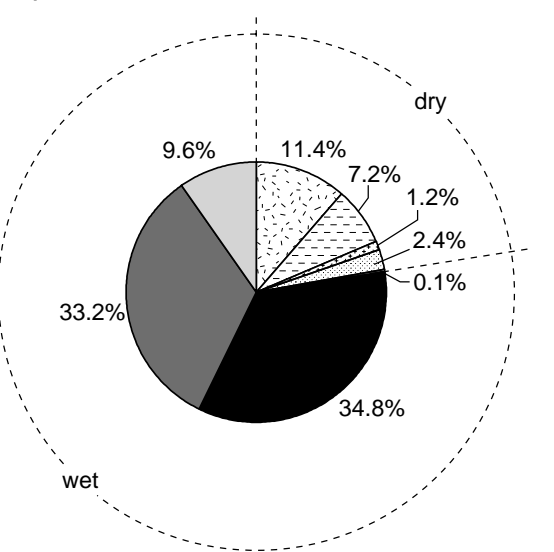

b) transition period

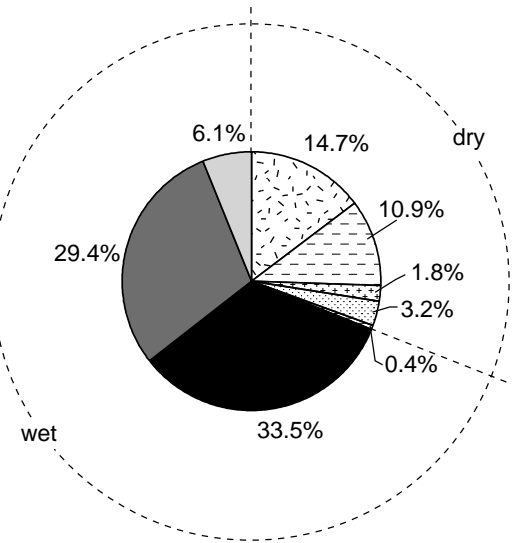

$$
\begin{aligned}
& \text { 回 } \mathrm{NO}_{2} \\
& \text { m HONO } \\
& \text { ㅁ } \mathrm{NH}_{3} \\
& \text { 因 } \mathrm{HNO}_{3} \\
& \square \text { aerosol } \mathrm{NH}_{4}{ }^{+} \\
& \text {目 aerosol } \mathrm{NO}_{3} \\
& \text { Ammonium } \\
& \square \text { Nitrate } \\
& \square \text { Nitrite }
\end{aligned}
$$

Fig. 12. Contribution of individual inorganic $\mathrm{N}$ compounds to the estimated total $\mathrm{N}$ deposition for (a) September (dry season, biomass burning), (b) October (transition period) and (c) November (wet season, clean conditions) at FNS during LBA-SMOCC 2002. Dry deposition of gaseous species is presented using averages of lower and upper flux estimates.

characterized by downward fluxes (net deposition). Maximal net deposition values range from -4 to $-22 \mathrm{ngN} \mathrm{m}^{-2}$ $\mathrm{s}^{-1}$, whereas the lower scenario is characterized by values that are at least a factor of two smaller. Median nighttime fluxes (18:00-08:00 LT) are usually higher than during the day, which is mainly due to higher $\mathrm{NO}_{2}$ mixing ratios measured during nighttime (Fig. 2e).

Fluxes of aerosol $\mathrm{NH}_{4}^{+}$and $\mathrm{NO}_{3}^{-}, \mathrm{F}$ (aerosol) (Fig. 10): The estimated median diel flux of aerosol $\mathrm{NH}_{4}^{+}$for the dry season exhibits a net deposition pattern characterized by highest values just after 09:00 LT $\left(\sim-7 \mathrm{ngN} \mathrm{m}^{-2} \mathrm{~s}^{-1}\right)$, which is consistent with maximal aerosol $\mathrm{NH}_{4}^{+}$mixing ratios observed during this time (see Fig. 2g) and increased turbulent mixing (increasing $u_{*}$ ) after sunrise. Although aerosol $\mathrm{NH}_{4}^{+}$mixing ratios were generally lower during daytime, the dry deposition of aerosol $\mathrm{NH}_{4}^{+}$is estimated to be highest because of high $V_{p}$ predicted during sunlight hours (see Fig. 8). The median diel course of the aerosol $\mathrm{NO}_{3}^{-}$flux shown in Fig. 10 for the dry season resembles that estimated for aerosol $\mathrm{NH}_{4}^{+}$, although the net deposition flux was at least three times lower than for aerosol $\mathrm{NH}_{4}^{+}$, which is a consequence of lower aerosol $\mathrm{NO}_{3}^{-}$mixing ratios (see Fig. $2 \mathrm{~g}$, h). The highest aerosol $\mathrm{NO}_{3}^{-}$net deposition is predicted at around 09:00 LT ( $\left.\sim 2 \mathrm{ngN} \mathrm{m}^{-2} \mathrm{~s}^{-1}\right)$.

\subsection{Seasonal cycles of $\mathrm{N}$ dry and wet deposition}

Figure 11a, b illustrates the estimated monthly $\mathrm{N}$ dry deposition (downward flux only) for $\mathrm{NO}_{2}$, total ammonium, total nitrate and total nitrite. The dry deposition rates of $\mathrm{NO}_{2}$ and total ammonium $\left(\mathrm{NH}_{3}+\right.$ aerosol $\left.\mathrm{NH}_{4}^{+}\right)$are estimated to be highest and decline by about $70 \%$ from September (late dry season, biomass burning) to November (onset of the wet season, clean conditions) (Fig. 11a). This indicates the influence of biomass burning during the dry season, which significantly enhances the dry deposition fluxes of $\mathrm{NO}_{2}$ and $\mathrm{NH}_{3}$. The dry deposition of total nitrate $\left(\mathrm{HNO}_{3}+\right.$ aerosol $\left.\mathrm{NO}_{3}^{-}\right)$ also decreases by about 70\% from September to November, but was on average 4 times lower than that of $\mathrm{NO}_{2}$ and total ammonium. This is in accordance with lower mixing 


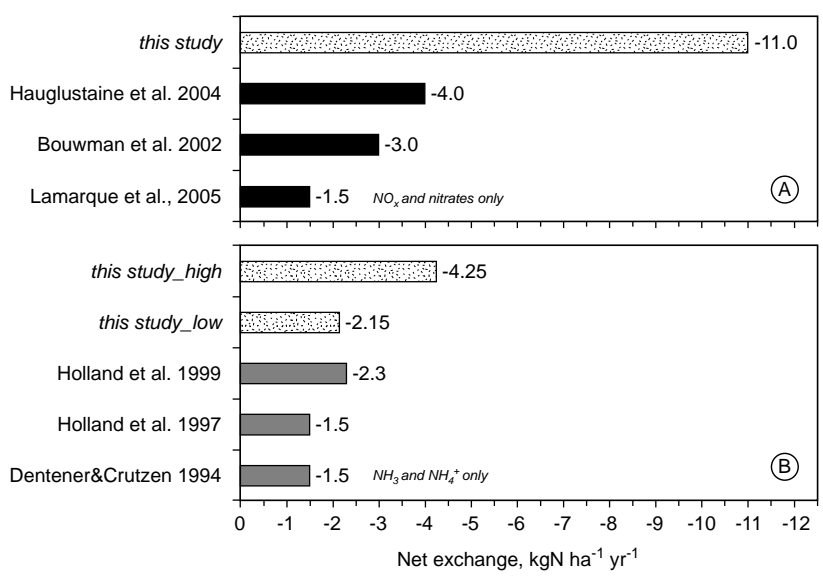

Fig. 13. Comparison of the annual $\mathrm{N}$ (wet + dry) deposition predicted by global chemistry and transport models for the Amazon region with the net annual $\mathrm{N}$ (wet + dry) exchange estimated in this study. Panel (A) represents the case when $\mathrm{NH}_{3}$ is considered to be deposited only and in panel (B) the lower ("this study_low") and upper ("this study_high") bi-directional flux estimates are shown.

ratios observed for nitrate in gas and aerosol phase (Table 2) (cf. Trebs et al., 2004). The contribution of nitrite (HONO) to the dry deposition in September is smallest, and is negligible in October and November.

The estimated $\mathrm{N}$ wet deposition (Fig. 11b) is considerably higher than $\mathrm{N}$ dry deposition at the FNS site. The obtained wet deposition rate of nitrate is consistent with the results of Lara et al. (2006). N wet removal is dominated by ammonium and nitrate, and wet deposition of nitrite is at least 3 times smaller. Interestingly, the decrease of wet deposition of ammonium and nitrate from September to November is only $\sim 20 \%$, hence, much less pronounced than that found for $\mathrm{N}$ dry deposition.

During the late dry season (biomass burning) in September, on average $46.4 \%$ of the total $\mathrm{N}$ deposition can be attributed to dry deposition and $\sim 53.6 \%$ to wet deposition (Fig. 12a). With increasing rainfall amounts, the contribution of dry deposition drops to only $31 \%$ and $22.4 \%$ to the total $\mathrm{N}$ deposition during October (transition period) and November (onset of the wet season, clean conditions), respectively (Fig. 12b, c).

$\mathrm{N}$ dry deposition at FNS was dominated by $\mathrm{NO}_{2}$ and $\mathrm{NH}_{3}$. During September (dry season, Fig. 12a) the contribution of $\mathrm{NO}_{2}$ and $\mathrm{NH}_{3}$ to the total $\mathrm{N}$ deposition is estimated to be $21.4 \%$ and $15.4 \%$, respectively. By contrast, the $\mathrm{N}$ dry deposition of $\mathrm{HNO}_{3}$ and $\mathrm{HONO}$ is estimated to be small, contributing only $2.7 \%$ and $1.4 \%$ to the total $\mathrm{N}$ deposition during the dry season, respectively (Fig. 12a). Aerosol $\mathrm{NH}_{4}^{+}$ and aerosol $\mathrm{NO}_{3}^{-}$show comparably small contributions to the total $\mathrm{N}$ deposition during the dry season $(4.5 \%$ and $1.1 \%$, respectively).
Through the transition period (October) until the wet season (November), the contribution of $\mathrm{NO}_{2}$ dry deposition to the total deposition declines to about $11 \%$ (Fig. 12b, c). The relative contribution of $\mathrm{NH}_{3}$ to the total estimated $\mathrm{N}$ deposition decreases to $11 \%$ during the transition period and to about $7 \%$ during the wet season. The $\mathrm{N}$ dry removal associated with $\mathrm{HNO}_{3}, \mathrm{HONO}$ and aerosol $\mathrm{NH}_{4}^{+}$and $\mathrm{NO}_{3}^{-}$is estimated to be negligibly small during the transition period and the wet season $(<6 \%$ in total).

\subsection{Annual budget of surface-atmosphere exchange}

The annual budget of surface-atmosphere exchange of inorganic $\mathrm{N}$ species at the FNS pasture site has been determined making the following assumptions: (i.) September is representative for the entire dry season (May to September) $\left(\mathrm{PM}_{10}=100-200 \mu \mathrm{g} \mathrm{m}^{-3}\right)$, (ii.) October is representative for the two transition periods (April and October) $\left(\mathrm{PM}_{10}=50\right.$ $100 \mu \mathrm{g} \mathrm{m}^{-3}$ ), and (iii.) November is representative for the entire wet season (November to March) $\left(\mathrm{PM}_{10} \leq 25 \mu \mathrm{g} \mathrm{m}^{-3}\right)$ (Artaxo et al., 2002). If $\mathrm{NH}_{3}$ is considered to be deposited only to the pasture site (i.e., no bi-directional exchange, cf. Fig. 9a), the annual $\mathrm{N}$ budget (i.e., the annual net $\mathrm{N}$ exchange at the pasture site) would be $-11 \mathrm{kgN} \mathrm{ha}^{-1} \mathrm{yr}^{-1}$. Using the bi-directional scenarios, the annual $\mathrm{N}$ (wet + dry) deposition is estimated to range between -6.83 and $-8.94 \mathrm{kgN}$ $\mathrm{ha}^{-1} \mathrm{yr}^{-1}$. Thereof, -1.57 to $-3.68 \mathrm{kgN} \mathrm{ha}^{-1} \mathrm{yr}^{-1}$ can be attributed to dry deposition and $\sim-5.26 \mathrm{kgN} \mathrm{ha}^{-1} \mathrm{yr}^{-1}$ to wet deposition. Our estimates suggest that 2.58 to $6.79 \mathrm{kgN}$ $\mathrm{ha}^{-1} \mathrm{yr}^{-1}$ may be emitted in form of gaseous $\mathrm{NH}_{3}, \mathrm{HONO}$ and NO from the pasture site (the annual estimate for NO emission was taken from Kirkman et al., 2002), whereof at least $90 \%$ are expected to be in the form of $\mathrm{NH}_{3}$. Thus, considering the bi-directional scenarios, the annual $\mathrm{N}$ budget may range from -2.15 to $-4.25 \mathrm{kgN} \mathrm{ha}^{-1} \mathrm{yr}^{-1}$ (cf. Fig. 13).

Regarding soil emission of nitrous oxide $\left(\mathrm{N}_{2} \mathrm{O}\right)$, not included in this study, Garcia-Montiel et al. (2003) reported that the emission of $\mathrm{N}_{2} \mathrm{O}$ from Rondônian pastures is even smaller than that of NO. Kirkman et al. (2002) estimated that the FNS site constitutes a $\mathrm{NO}_{2}$ sink of $-0.73 \mathrm{kgN} \mathrm{ha}^{-1} \mathrm{yr}^{-1}$. They assumed that their measurements from 24 September to 27 October 1999 (dry-wet transition period) were representative for the wet and dry season and that these seasons are about equal in length. However, based on our measurements and using the minimal and maximal $R_{C}\left(\mathrm{NO}_{2}\right)$ values of Kirkman et al. (2002), our annual $\mathrm{NO}_{2}$ deposition estimate ranges from -0.76 to $-2.4 \mathrm{kgN} \mathrm{ha}^{-1} \mathrm{yr}^{-1}$, which is considerably higher, mainly due to higher $\mathrm{NO}_{2}$ mixing ratios observed in our study.

Moreover, it should be noted that water-soluble organic nitrogen (WSON) constitutes a significant part of the total $\mathrm{N}$ fraction of Amazonian aerosols. It was found by Mace et al. (2003), that organic $\mathrm{N}$ may represent $45 \%$ and $43 \%$ of the total $\mathrm{N}$ in wet and dry season aerosol samples, respectively. Obviously, the total deposition of atmospheric $\mathrm{N}$ would be 
significantly higher if these organic species were also taken into account.

Finally, Fig. 13 shows a comparison of our estimated annual net $\mathrm{N}$ exchange with predictions for annual $\mathrm{N}$ (wet +dry) deposition by global chemistry and transport models (CTMs) (Dentener and Crutzen, 1994; Holland et al., 1997, 1999; Bouwman et al., 2002; Hauglustaine et al., 2004; Lamarque et al., 2005). The values from Dentener and Crutzen (1994) and Holland et al. (1997) are averages of N deposition predicted for the Amazon region (MOGUNTIA model). The estimates from Dentener and Crutzen (1994) exclude dry deposition of $\mathrm{NO}_{\mathrm{x}}$ and nitrates. Holland et al. (1999) (MOGUNTIA) present predictions for tropical grasslands, considering all components of $\mathrm{N}$ exchange. Bouwman et al. (2002) (STOCHEM model), Hauglustaine et al. (2004) (LMDz-INCA model) and Lamarque et al. (2005) provide the $\mathrm{N}$ deposition for South America, but do not take into account bi-directional exchange of $\mathrm{NH}_{3}$. The most recent study by Lamarque et al. (2005) (average of six different CTMs) presents $\mathrm{N}$ deposition resulting from $\mathrm{NO}_{\mathrm{x}}$ and nitrates, excluding deposition of $\mathrm{NH}_{3}$. In the case where $\mathrm{NH}_{3}$ is considered to be deposited only (Fig. 13, panel A) our estimates exceed those of global CTMs by more than a factor of two. In case of bi-directional exchange (Fig. 13, panel B), the result of our lower scenario agrees relatively well with predictions by global CTMs, whereas the result of the upper scenario is two times higher than CTM estimates.

It is noteworthy that the FNS site is situated in one of the most disturbed regions of the Brazilian Amazon. During the dry season, the site is characterized by high pollution levels compared to other Amazonian ecosystems. In remote Central Amazonia (smaller fire frequency/density), wet deposition rates of nitrate and ammonium were previously estimated by Stallard and Edmond (1981), Andreae et al. (1990) and Williams et al. (1997) to be $-1.7 \mathrm{kgN} \mathrm{ha}^{-1} \mathrm{yr}^{-1},-2.1 \mathrm{kgN}$ $\mathrm{ha}^{-1} \mathrm{yr}^{-1}$ and $-2.8 \mathrm{kgN} \mathrm{ha}^{-1} \mathrm{yr}^{-1}$, respectively. The corresponding value from our study $\left(-4.7 \mathrm{kgN} \mathrm{ha}^{-1} \mathrm{yr}^{-1}\right.$; wet deposition of ammonium + nitrate, nitrite excluded) is about twice as high as these results. However, the estimates of total $\mathrm{N}$ (dry + wet) deposition (see Fig. 13), calculated by global CTMs (which consider remote as well as polluted conditions), are equal to the deposition (wet only) rates for remote Amazonian sites given by Stallard and Edmond (1981), Andreae et al. (1990) and Williams et al. (1997).

\section{Summary and conclusions}

We have estimated dry and wet deposition of inorganic $\mathrm{N}$ at a tropical pasture site (Rondonia, Brazil) based on real-time measurements of inorganic $\mathrm{N}$ containing gases and aerosol species during the late dry (biomass burning) season, the transition period and the onset of the wet season (clean conditions) (LBA-SMOCC 2002). $\mathrm{HNO}_{3}, \mathrm{NO}_{2}$, aerosol $\mathrm{NH}_{4}^{+}$and $\mathrm{NO}_{3}^{-}$were considered to be net deposited to the pasture site under all ambient conditions, while surface-atmosphere exchange of $\mathrm{HONO}$ and $\mathrm{NH}_{3}$ is considered to be bi-directional. All fluxes have been determined by inferential techniques, making use of aerodynamic and surface related resistances that have been deduced from measurements or were taken from recent literature. For the least-well defined quantities, lower and upper cases have been considered. Bi-directional $\mathrm{NH}_{3}$ fluxes were predicted using a dynamic resistance model from Sutton et al. (1998). $\mathrm{NO}_{2}$ and $\mathrm{NH}_{3}$ are the most important contributors to $\mathrm{N}$ dry deposition and their fluxes largely control the net $\mathrm{N}$ exchange pattern at the pasture site. Mixing ratios of $\mathrm{NO}_{2}$ and water-soluble $\mathrm{N}$ species in gas and aerosol phase are significantly enhanced when widespread biomass burning takes place during the dry season, resulting in high $\mathrm{N}$ deposition rates. The contribution of $\mathrm{N}$ dry deposition to the total $\mathrm{N}($ dry + wet) deposition decreased substantially from the dry (biomass burning) season to the wet season. In the case where bi-directional $\mathrm{NH}_{3}$ exchange is considered, our results suggest that the annual $\mathrm{N}$ budget at the pasture site may range from -2.15 to $-4.25 \mathrm{kgN} \mathrm{ha}^{-1} \mathrm{yr}^{-1}$. When $\mathrm{NH}_{3}$ is assumed to be deposited only, the overall net exchange is $-11 \mathrm{kgN} \mathrm{ha}^{-1} \mathrm{yr}^{-1}$.

The largest uncertainties in our estimates are related to the bi-directional $\mathrm{NH}_{3}$ exchange, namely (i.) the surface water (epicuticular) $\mathrm{pH}$, (ii.) the ratio of $\mathrm{NH}_{4}^{+}$and $\mathrm{H}^{+}$concentration in the apoplastic fluid $(\Gamma)$ and (iii.) direct $\mathrm{NH}_{3}$ emissions from cattle excreta. These quantities strongly control the $\mathrm{NH}_{3}$ canopy compensation point concentration. In this study, low values of (i.) the epicuticular $\mathrm{pH}(4-4.5)$ and (ii.) the ratio of $\mathrm{NH}_{4}^{+}$and $\mathrm{H}^{+}$concentration in the apoplastic fluid ( $\Gamma=100-200)$ were adopted. The latter can be justified by the low soil $\mathrm{N}$ status of the pasture. Choosing this parameterization, the characteristic diel pattern of the $\mathrm{NH}_{3}$ exchange found in temperate latitudes could be reproduced (daytime net emission, nighttime net deposition). A comparison of our results to those of global CTMs suggests that net $\mathrm{N}$ deposition rates to Amazonian pastures may be higher than currently predicted by global CTMs.

Acknowledgements. The data presented in this study were acquired within the framework of the Large Scale Biosphere Atmosphere Experiment in Amazonia (LBA). The authors gratefully acknowledge financial support by the European Commission (contract $\mathrm{N}^{\circ}$ EVK2-CT-2001-00110 SMOCC), by the Max Planck Society and the Brazilian financial agencies that have supported the projects FAPESP (RACCI) and CNPq (MilênioLBA). The authors are grateful to L. Ganzeveld for his valuable comments on the paper and to M. A. L. Moura and R. S. da Silva (Jr.) for performing some of the meteorological measurements. We are indebted to E. Swietlicki and A. Vestin for supplying the data and information about the dry aerosol particle size distribution measured during the SMOCC field campaign. Furthermore, we would like to thank E. Nemitz and two anonymous reviewers for stimulating a fruitful discussion, due to which some results presented in the discussion version of the paper could be revised.

Edited by: D. Rosenfeld 


\section{References}

Alicke, B., Geyer, A., Hofzumahaus, A., Holland, F., Konrad, S., Patz, H. W., Schafer, J., Stutz, J., Volz-Thomas, A., and Platt, U.: $\mathrm{OH}$ formation by $\mathrm{HONO}$ photolysis during the BERLIOZ experiment, J. Geophys. Res.-Atmos., 108, 8247, doi:8210.1029/2001JD000579, 2003.

Ammann, C.: On the applicability of relaxed eddy accumulation and common methods for measuring trace gas fluxes, Zürcher Geopgraphische Schriften, ETH, Zürich, 1-50, 1999.

Andreae, M. O., Rosenfeld, D., Artaxo, P., Costa, A. A., Frank, G. P., Longo, K. M., and Silva-Dias, M. A. F.: Smoking rain clouds over the Amazon, Science, 303, 5662, 1337-1342, 2004.

Andreae, M. O., Artaxo, P., Brandao, C., Carswell, F. E., Ciccioli, P., da Costa, A. L., Culf, A. D., Esteves, J. L., Gash, J. H. C., Grace, J., Kabat, P., Lelieveld, J., Malhi, Y., Manzi, A. O., Meixner, F. X., Nobre, A. D., Nobre, C., Ruivo, M., Silva-Dias, M. A., Stefani, P., Valentini, R., von Jouanne, J., and Waterloo, M. J.: Biogeochemical cycling of carbon, water, energy, trace gases, and aerosols in Amazonia: The LBAEUSTACH experiments, J. Geophys. Res.-Atmos., 107, 8066, doi:8010.1029/2001JD000524, 2002.

Andreae, M. O., Talbot, R. W., Berresheim, H., and Beecher, K. M.: Precipitation Chemistry in Central Amazonia, J. Geophys. Res.-Atmos., 95, 16987-16999, 1990.

Araujo, A. C., Nobre, A. D., Kruijt, B., Elbers, J. A., Dallarosa, R., Stefani, P., von Randow, C., Manzi, A. O., Culf, A. D., Gash, J. H. C., Valentini, R., and Kabat, P.: Comparative measurements of carbon dioxide fluxes from two nearby towers in a central Amazonian rainforest: The Manaus LBA site, J. Geophys. Res.Atmos., 107, 8090, doi:10.1029/2001JD000676, 2002.

Artaxo, P., Martins, J. V., Yamasoe, M. A., Procopio, A. S., Pauliquevis, T. M., Andreae, M. O., Guyon, P., Gatti, L. V., and Leal, A. M. C.: Physical and chemical properties of aerosols in the wet and dry seasons in Rondonia, Amazonia, J. Geophys. Res.-Atmos., 107, 8081, doi:10.1029/2001JD000666, 2002.

Asner, G. P., Townsend, A. R., Riley, W. J., Matson, P. A., Neff, J. C., and Cleveland, C. C.: Physical and biogeochemical controls over terrestrial ecosystem responses to nitrogen deposition, Biogeochemistry, 54, 1-39, 2001.

Boddey, R. M., Macedo, R., Tarre, R. M., Ferreira, E., de Oliveira, O. C., Rezende, C. D., Cantarutti, R. B., Pereira, J. M., Alves, B. J. R., and Urquiaga, S.: Nitrogen cycling in Brachiaria pastures: the key to understanding the process of pasture decline, Agriculture Ecosystems \& Environment, 103, 389-403, 2004.

Bouwman, A. F., Van Vuuren, D. P., Derwent, R. G., and Posch, M.: A global analysis of acidification and eutrophication of terrestrial ecosystems, Water Air and Soil Pollution, 141, 349-382, 2002.

Brunnemann, G., Kins, L., and Dlugi, R.: Physical and chemical characterisation of the atmospheric aerosol: An overview of the measurements during the SANA 2 campaign at Melpitz, Meteorologische Zeitschrift, N.F. 5, 245-256, 1996.

Clark, K. L., Nadkarni, N. M., Schaefer, D., and Gholz, H. L.: Atmospheric deposition and net retention of ions by the canopy in a tropical montane forest, Monteverde, Costa Rica, Journal of Tropical Ecology, 14, 27-45, 1998.

Culf, A. D., Esteves, J. L., de O. Marques Filho, A., and Da Rocha, H. R.: Radiation, temperature and humidity over forest and pasture in Amazonia, Amazonian Deforestation and Climate, edited by: Gash, J. H. C., Nobre, C. A., Roberts, J. M., and Victoria, R.
L., New York, John Wiley, 413-424, 1996.

Davidson, E. A., Carvalho, C. J. R., Vieira, I. C. G., Figueiredo, R. O., Moutinho, P., Ishida, F. Y., dos Santos, M. T. P., Guerrero, J. B., Kalif, K., and Sabá, R. T.: Nutrient limitation of biomass growth in a tropical secondary forest: Early results of a nitrogen and phosphorus amendment experiment, Ecological Applications, 14(4) Supplement, S150-S163, 2004.

De Arellano, J. V.-G. and Duynkerke, P. G.: Influence of Chemistry on the Flux-Gradient Relationships for the $\mathrm{NO}-\mathrm{O}_{3}-\mathrm{NO}_{2}$ System, Boundary-Layer Meteorol., 61, 375-387, 1992.

Dentener, F. J. and Crutzen, P. J.: A 3-Dimensional Model of the Global Ammonia Cycle, J. Atmos. Chem., 19, 331-369, 1994.

Dlugi, R.: Interaction of $\mathrm{NO}_{\mathrm{x}}$ and VOCs within vegetation. Photooxidants: Precursors and Products, in: Proceedings of EUROTRAC Symposium '92, edited by: Borrell, P. B. P. M., Cvitas, T., and Seiler, W., The Hague, Academic Publishing, 682-688, 1993.

Dollard, G. J., Atkins, D. H. F., Davies, T. J., and Healy, C.: Concentrations and Dry Deposition Velocities of Nitric-Acid, Nature, 326, 481-483, 1987.

Erisman, J. W., Vanpul, A., and Wyers, P.: Parametrization of Surface-Resistance for the Quantification of Atmospheric Deposition of Acidifying Pollutants and Ozone, Atmos. Environ., 28, 2595-2607, 1994.

Erisman, J. W., Vermetten, A. W. M., Asman, W. A. H., WaijersIjpelaan, A., and Slanina, J.: Vertical-Distribution of Gases and Aerosols - the Behavior of Ammonia and Related Components in the Lower Atmosphere, Atmos. Environ., 22, 1153-1160, 1988.

Erisman, J. W. and Wyers, G. P.: Continuous Measurements of Surface Exchange of $\mathrm{SO}_{2}$ and $\mathrm{NH}_{3}$ - Implications for Their Possible Interaction in the Deposition Process, Atmos. Environ. Part a-General Topics, 27, 1937-1949, 1993.

Falkovich, A. H., Graber, E. R., Schkolnik, G., Rudich, Y., Maenhaut, W., and Artaxo, P.: Low molecular weight organic acids in aerosol particles from Rondônia, Brazil, during the biomassburning, transition and wet periods, Atmos. Chem. Phys., 5, 781797, 2005,

SRef-ID: 1680-7324/acp/2005-5-781.

Farquhar, G. D., Firth, P. M., Wetselaar, R., and Weir, B.: On the Gaseous Exchange of Ammonia between Leaves and the Environment - Determination of the Ammonia Compensation Point, Plant Physiol., 66, 710-714, 1980.

Fehsenfeld, F. C., Drummond, J. W., Roychowdhury, U. K., Galvin, P. J., Williams, E. J., Buhr, M. P., Parrish, D. D., Hubler, G., Langford, A. O., Calvert, J. G., Ridley, B. A., Grahek, F., Heikes, B. G., Kok, G. L., Shetter, J. D., Walega, J. G., Elsworth, C. M., Norton, R. B., Fahey, D. W., Murphy, P. C., Hovermale, C., Mohnen, V. A., Demerjian, K. L., Mackay, G. I., and Schiff, H. I.: Intercomparison of $\mathrm{NO}_{2}$ Measurement Techniques, J. Geophys. Res.-Atmos., 95, 3579-3597, 1990.

Fisch, G., Tota, J., Machado, L. A. T., Dias, M., Lyra, R. F. D., Nobre, C. A., Dolman, A. J., and Gash, J. H. C.: The convective boundary layer over pasture and forest in Amazonia, Theoretical and Applied Climatology, 78, 47-59, 2004.

Flechard, C. R., Fowler, D., Sutton, M. A., and Cape, J. N.: A dynamic chemical model of bi-directional ammonia exchange between semi-natural vegetation and the atmosphere, Q. J. R. Meteor. Soc., 125, 2611-2641, 1999. 
Gallagher, M. W., Fontan, J., Wyers, G. P., Ruijgrok, W., Duyzer, J., Hummelshoj, P., Pilegaard, K., and Fowler, D.: Atmospheric particles and their interactions with natural surfaces, Biosphere-Atmosphere Exchange of Pollutants and Trace substances EUROTRAC-BIATEX, edited by: Slanina, J., Springer, 4, 45-92, 1997.

Galloway, J. N.: The global nitrogen cycle: changes and consequences, Environ. Pollut., 102, 15-24, 1998.

Galloway, J. N., Likens, G. E., Keene, W. C., and Miller, J. M.: The Composition of Precipitation in Remote Areas of the World, J. Geophys. Res.-Oceans and Atmospheres, 87, 8771-8786, 1982.

Galy-Lacaux, C., Carmichaël, G. R., Song, C. H., Lacaux, J. P., and Galwa, J.: Dry and wet atmospheric nitrogen deposition in Africa, IGAC Newsletter Article, 27, 6-11, 2003.

Garcia-Montiel, D. C., Steudler, P. A., Piccolo, M., Neill, C., Melillo, J., and Cerri, C. C.: Nitrogen oxide emissions following wetting of dry soils in forest and pastures in Rondonia, Brazil, Biogeochem., 64, 319-336, 2003.

Garland, J. A.: On the size dependence of particle deposition, Water, Air and Soil Pollution: Focus, 1(5-6), 323-332, 2001.

Garratt, J. R.: The atmospheric boundary layer, Cambridge, 315, Cambridge University Press, 1992.

Goulding, K. W. T., Bailey, N. J., Bradbury, N. J., Hargreaves, P., Howe, M., Murphy, D. V., Poulton, P. R., and Willison, T. W.: Nitrogen deposition and its contribution to nitrogen cycling and associated soil processes, New Phytologist, 139, 49-58, 1998.

Hall, S. J. and Matson, P. A.: Nitrogen oxide emissions after nitrogen additions in tropical forests, Nature, 400, 152-155, 1999.

Hanson, P. J. and Lindberg, S. E.: Dry Deposition of Reactive Nitrogen-Compounds - a Review of Leaf, Canopy and NonFoliar Measurements, Atmos. Environ. Part a-General Topics, 25, 1615-1634, 1991.

Harrison, R. M. and Kitto, A. M. N.: Evidence for a Surface Source of Atmospheric Nitrous-Acid, Atmos. Environ., 28, 1089-1094, 1994.

Harrison, R. M., Peak, J. D., and Collins, G. M.: Tropospheric cycle of nitrous acid, J. Geophys. Res.-Atmos., 101, 14 429-14439, 1996.

Harrison, R. M., Sturges, W. T., Kitto, A. M. N., and Li, Y. Q.: Kinetics of Evaporation of Ammonium-Chloride and AmmoniumNitrate Aerosols, Atmos. Environ. Part a-General Topics, 24, 1883-1888, 1990.

Hauglustaine, D. A., Hourdin, F., Jourdain, L., Filiberti, M. A., Walters, S., Lamarque, J. F., and Holland, E. A.: Interactive chemistry in the Laboratoire de Meteorologie Dynamique general circulation model: Description and background tropospheric chemistry evaluation, J. Geophys. Res.-Atmos., 109, D04314, doi:10.1029/2003JD003957, 2004.

Hesterberg, R., Blatter, A., Fahrni, M., Rosset, M., Neftel, A., Eugster, W., and Wanner, H.: Deposition of nitrogen-containing compounds to an extensively managed grassland in central Switzerland, Environ. Pollut., 91, 21-34, 1996.

Hicks, B. B., Baldocchi, D. D., Meyers, T. P., Hosker, R. P., and Matt, D. R.: A Preliminary Multiple Resistance Routine for Deriving Dry Deposition Velocities from Measured Quantities, Water Air and Soil Pollution, 36, 311-330, 1987.

Holland, E. A., Braswell, B. H., Lamarque, J. F., Townsend, A., Sulzman, J., Muller, J. F., Dentener, F., Brasseur, G., Levy, H., Penner, J. E., and Roelofs, G. J.: Variations in the predicted spatial distribution of atmospheric nitrogen deposition and their impact on carbon uptake by terrestrial ecosystems, J. Geophys. Res.-Atmos., 102, 15 849-15 866, 1997.

Holland, E. A., Dentener, F. J., Braswell, B. H., and Sulzman, J. M.: Contemporary and pre-industrial global reactive nitrogen budgets, Biogeochem., 46, 7-43, 1999.

Howarth, R. W., Billen, G., Swaney, D., Townsend, A., Jaworski, N., Lajtha, K., Downing, J. A., Elmgren, R., Caraco, N., Jordan, T., Berendse, F., Freney, J., Kudeyarov, V., Murdoch, P., and Zhu, Z. L.: Regional nitrogen budgets and riverine N\&P fluxes for the drainages to the North Atlantic Ocean: Natural and human influences, Biogeochem., 35, 75-139, 1996.

Huebert, B. J. and Robert, C. H.: The Dry Deposition of Nitric-Acid to Grass, J. Geophys. Res.-Atmos., 90, 2085-2090, 1985

Kauffman, J. B., Cummings, D. L., and Ward, D. E.: Fire in the Brazilian Amazon 2. Biomass, nutrient pools and losses in cattle pastures, Oecologia, 113, 415-427, 1998.

Kauffman, J. B., Cummings, D. L., Ward, D. E., and Babbitt, R.: Fire in the Brazilian Amazon 1. Biomass, Nutrient Pools, and Losses in Slashed Primary Forests, Oecologia, 104, 397-408, 1995.

Khlystov, A.: Cloud forming properties of ambient aerosol in the Netherlands and resultant shortwave radiative forcing of climate, Dept. of acgricultural sciences, Wageningen, University of Wageningen, 1998.

Khlystov, A., Wyers, G. P., and Slanina, J.: The Steam-Jet Aerosol Collector, Atmos. Environ., 29, 2229-2234, 1995.

Kirkman, G. A., Gut, A., Ammann, C., Gatti, L. V., Cordova, A. M., Moura, M. A. L., Andreae, M. O., and Meixner, F. X.: Surface exchange of nitric oxide, nitrogen dioxide, and ozone at a cattle pasture in Rondonia, Brazil, J. Geophys. Res.-Atmos., 107, 8083, doi:8010.1029/2001JD000523, 2002.

Kramm, G. and Dlugi, R.: Modeling of the Vertical Fluxes of NitricAcid, Ammonia, and Ammonium-Nitrate, J. Atmos. Chem., 18, 319-357, 1994.

Kraus, A. and Hofzumahaus, A.: Field measurements of atmospheric photolysis frequencies for $\mathrm{O}_{3}, \mathrm{NO}_{2}, \mathrm{HCHO}, \mathrm{CH}_{3} \mathrm{CHO}$, $\mathrm{H}_{2} \mathrm{O}_{2}$, and $\mathrm{HONO}$ by UV spectroradiometry, J. Atmos. Chem., 31, 161-180, 1998.

Lamarque, J. F., Kiehl, J. T. , Brasseur, G. P., Butler, T., CameronSmith, P., Collins, W. D., Collins, W. J., Granier, C., Hauglustaine, D., Hess, P. G., Holland, E. A., Horowitz, L., Lawrence, M. G., McKenna, D., Merilees, P., Prather, M. J., Rasch, P. J., Rotman, D., Shindell, D., and Thornton, P.: Assessing future nitrogen deposition and carbon cycle feedback using a multimodel approach: Analysis of nitrogen deposition, J. Geophys Res.-Atmos., 110, D19303, doi:10.1029/2005JD005825, 2005.

Lammel, G. and Cape, J. N.: Nitrous acid and nitrite in the atmosphere, Chem. Soc. Rev., 25, 361-369, 1996.

Lara, L., Artaxo, P., Martinelli, L. A., Victoria, R. L., Camargo, P. B., Krusche, A., Ayers, G. P., Ferraz, E. S. B., and Ballester, M. V.: Chemical composition of rainwater and anthropogenic influences in the Piracicaba River Basin, Southeast Brazil, Atmos. Environ., 35, 4937-4945, 2001

Lara, L., Holland, E. A., Artaxo, P., Camargo, P. B., and Martinelli, L. A.: Linking biomass burning and nitrogen pattern deposition in tropical regions, Biogeochem., in press, 2006.

Lenschow, D. H.: Reactive trace species in the boundary layer from a micrometeorological perspective, J. Meteorol. Soc. Jpn., 60, 
161-172, 1982.

Lesack, L. F. W. and Melack, J. M.: The Deposition, Composition, and Potential Sources of Major Ionic Solutes in Rain of the Central Amazon Basin, Water Resour. Res., 27, 2953-2977, 1991.

Likens, G. E., Keene, W. C., Miller, J. M., and Galloway, J. N.: Chemistry of Precipitation from a Remote, Terrestrial Site in Australia, J. Geophys. Res.-Atmos., 92, 13 299-13 314, 1987.

Loubet, B., Milford, C., Hill, P. W., Tang, Y. S., Cellier, P., and Sutton, M. A.: Seasonal variability of apoplastic $\mathrm{NH}_{4}^{+}$and $\mathrm{pH}$ in an intensively managed grassland, Plant and Soil, 238, 97-110, 2002.

Mace, K. A., Artaxo, P., and Duce, R. A.: Water-soluble organic nitrogen in Amazon Basin aerosols during the dry (biomass burning) and wet seasons, J. Geophys. Res.-Atmos., 108, 4512, doi:4510.1029/2003JD003557, 2003.

Matson, P. A., McDowell, W. H., Townsend, A. R., and Vitousek, P. M.: The globalization of $\mathrm{N}$ deposition: ecosystem consequences in tropical environments, Biogeochem., 46, 67-83, 1999.

Meixner, F. X.: Surface exchange of odd nitrogen oxides, Nova Acta Leopoldina, 70, 299-348, 1994.

Meixner, F. X., Wyers, G. P., and Neftel, A.: Bi-directional exchange of ammonia over cereals, in: Proceedings of EUROTRAC Symposium '96, edited by: Borrell, P. B. P. M., Cvitas, T., Kelly, K., and Seiler, W., Southhampton, Computational Mechanics Publications, 1996.

Meng, Z. Y. and Seinfeld, J. H.: Time scales to achieve atmospheric gas-aerosol equilibrium for volatile species, Atmos. Environ., 30, 2889-2900, 1996.

Müller, H., Kramm, G., Meixner, F., Dollard, G. J., Fowler, D., and Possanzini, M.: Determination of $\mathrm{HNO}_{3}$ Dry Deposition by Modified Bowen-Ratio and Aerodynamic Profile Techniques, Tellus Series B-Chemical and Physical Meteorology, 45, 346367, 1993.

Nemitz, E., Sutton, M. A., Wyers, G. P., and Jongejan, P. A. C.: Gas-particle interactions above a Dutch heathland: I. Surface exchange fluxes of $\mathrm{NH}_{3}, \mathrm{SO}_{2}, \mathrm{HNO}_{3}$ and $\mathrm{HCl}$, Atmos. Chem. Phys., 4, 989-1005, 2004a,

SRef-ID: 1680-7324/acp/2004-4-989.

Nemitz, E., Sutton, M. A., Wyers, G. P., Otjes, R. P., Mennen, M. G., van Putten, E. M., and Gallagher, M. W.: Gas-particle interactions above a Dutch heathland: II. Concentrations and surface exchange fluxes of atmospheric particles, Atmos. Chem. Phys., 4, 1007-1024, 2004b,

\section{SRef-ID: 1680-7324/acp/2004-4-1007.}

Nicholson, K. W.: The Dry Deposition of Small Particles - a Review of Experimental Measurements, Atmos. Environ., 22, 2653-2666, 1988.

Nobre, C. A., Fisch, G., da Rocha, H. R., Lyra, R. F. D., da Rocha, E. P., da Costa, A. C. L., and Ubarana, V. N.: Observations of the atmospheric boundary layer in Rondônia, Amazonian Deforestation and Climate, edited by: Gash, J. H. C., Nobre, C. A., Roberts, J. M., and Victoria, R. L., New York, John Wiley, 413424, 1996.

Oliveira, O. C., Oliveira, I. P. d., Ferreira, E., Alves, B. J. R., Miranda, C. H. B., Vilela, L., Urquiaga, S., and Boddey, R. M.: Response of degraded pastures in the Brazilian Cerrado to chemical fertilisation, Pasturas Tropicales, 23, 14-18, 2001.

Pandis, S. N., Wexler, A. S., and Seinfeld, J. H.: Dynamics of Tropospheric Aerosols, J. Phys. Chem., 99, 9646-9659, 1995.
Phillips, S. B., Arya, S. P., and Aneja, V. P.: Ammonia Flux and dry deposition velocity from near-surface concentration gradient measurements over a grass surface in North Carolina, Atmos. Environ., 38, 3469-3480, 2004.

Rattray, G. and Sievering, H.: Dry deposition of ammonia, nitric acid, ammonium, and nitrate to alpine tundra at Niwot Ridge, Colorado, Atmos. Environ., 35, 1105-1109, 2001.

Reid, J. S. and Hobbs, P. V.: Physical and optical properties of young smoke from individual biomass fires in Brazil, J. Geophys. Res.-Atmos., 103, 32 013-32 030, 1998.

Reiners, W. A., Liu, S., Gerow, K. G., Keller, M., and Schimel, D. S.: Historical and future land use effects on $\mathrm{N}_{2} \mathrm{O}$ and $\mathrm{NO}$ emissions using an ensemble modeling approach: Costa Rica's Caribbean lowlands as an example, Global Biogeochem. Cycles, 16, 1068, doi:10.1029/2001GB001437, 2002.

Rissler, J., Swietlicki, E., Zhou, J., Roberts, G., Andreae, M. O., Gatti, L. V., and Artaxo, P.: Physical properties of the submicrometer aerosol over the Amazon rain forest during the wetto-dry season transition - comparison of modelled and measured CCN concentrations, Atmos. Chem. Phys., 4, 2119-2143, 2004, SRef-ID: 1680-7324/acp/2004-4-2119.

Ruijgrok, W., Davidson, C. I., and Nicholson, K. W.: Dry Deposition of Particles - Implications and Recommendations for Mapping of Deposition over Europe, Tellus Series B-Chemical and Physical Meteorology, 47, 587-601, 1995.

Russell, K. M., Keene, W. C., Maben, J. R., Galloway, J. N., and Moody, J. L.: Phase partitioning and dry deposition of atmospheric nitrogen at the mid-Atlantic US coast, J. Geophys. Res.Atmos., 108, 4656, doi:10.1029/2003JD003736, 2003.

Schimang, R., Folkers, A., Kleffman, J., Kleist, E., Miebach, M., and Wildt, J.: Uptake of gaseous nitrous acid (HONO) by several plant species, Atmos. Environ., 40, 1324-1335, 2006.

Schjoerring, J. K., Husted, S., and Mattsson, M.: Physiological parameters controlling plant-atmosphere ammonia exchange, Atmos. Environ., 32, 491-498, 1998a.

Seidl, W., Brunnemann, G., Kins, L., Köhler, E., Reuswig, K., and Dlugi, R.: On the ionic composition of aerosol particles and related gas phase species at two sites during the SANA 2 campaign, Meteorologische Zeitschrift, N.F. 5, 257-268, 1996.

Seinfeld, J. H. and Pandis, S. N.: Atmospheric Chemistry and Physics, New York, John Wiley \& Sons, Inc., 1998.

Singh, S. P., Satsangi, G. S., Khare, P., Lakhani, A., Maharaj Kumari, K., and Srivastava, S. S.: Multiphase measurement of atmospheric ammonia, Atmos. Environ., 3, 107-116, 2001.

Slanina, J., ten Brink, H. M., Otjes, R. P., Even, A., Jongejan, P., Khlystov, A., Waijers-Ijpelaan, A., and Hu, M.: The continuous analysis of nitrate and ammonium in aerosols by the steam jet aerosol collector (SJAC): extension and validation of the methodology, Atmos. Environ., 35, 2319-2330, 2001.

Slinn, W. G. N.: Predictions for Particle Deposition to Vegetative Canopies, Atmos. Environ., 16, 1785-1794, 1982.

Spindler, G., Teichmann, U., and Sutton, M. A.: Ammonia dry deposition over grassland - micrometeorological flux-gradient measurements and bidirectional flux calculations using an inferential model, Q. J. R. Meteor. Soc., 127, 795-814, 2001.

Srivastava, A. K. and Ambasht, R. S.: Nitrogen Deposition in Casuarina-Equisetifolia (Forst) Plantation Stands in the Dry Tropics of Sonbhadra, India, Forest Ecology and Management, 70, 341-348, 1994. 
Stallard, R. F. and Edmond, J. M.: Geochemistry of the Amazon 1. Precipitation Chemistry and the Marine Contribution to the Dissolved-Load at the Time of Peak Discharge, J. Geophys. Res.Oceans and Atmospheres, 86, 9844-9858, 1981.

Stutz, J., Alicke, B., and Neftel, A.: Nitrous acid formation in the urban atmosphere: Gradient measurements of $\mathrm{NO}_{2}$ and $\mathrm{HONO}$ over grass in Milan, Italy, J. Geophys. Res.-Atmos., 107, 8192, doi:8110.1029/2001JD000390, 2002.

Sutton, M. A., Asman, W. A. H., and Schjorring, J. K.: Dry Deposition of Reduced Nitrogen, Tellus Series B-Chemical and Physical Meteorology, 46, 255-273, 1994.

Sutton, M. A., Schjoerring, J. K., and Wyers, G. P.: Plantatmosphere exchange of ammonia, Phil. Trans. Roy. Soc., 351, 261-278, 1995.

Sutton, M. A., Burkhardt, J. K., Guerin, D., Nemitz, E., and Fowler, D.: Development of resistance models to describe measurements of bi-directional ammonia surface-atmosphere exchange, Atmos. Environ., 32, 473-480, 1998.

Sutton, M. A., Milford, C., Nemitz, E., Theobald, M. R., Hill, P. W., Fowler, D., Schjoerring, J. K., Mattsson, M. E., Nielsen, K. H., Husted, S., Erisman, J. W., Otjes, R., Hensen, A., Mosquera, J., Cellier, P., Loubet, B., David, M., Genermont, S., Neftel, A., Blatter, A., Herrmann, B., Jones, S. K., Horvath, L., Fuhrer, E. C., Mantzanas, K., Koukoura, Z., Gallagher, M., Williams, P., Flynn, M., and Riedo, M.: Biosphere-atmosphere interactions of ammonia with grasslands: Experimental strategy and results from a new European initiative, Plant and Soil, 228, 131-145, 2001.

Tarnay, L., Gertler, A. W., Blank, R. R., and Taylor, G. E.: Preliminary measurements of summer nitric acid and ammonia concentrations in the Lake Tahoe Basin air-shed: implications for dry deposition of atmospheric nitrogen, Environ. Pollut., 113, 145153, 2001.

Thom, A. S.: Vegetation and the atmosphere, Momentum, mass and heat exchange, edited by: Moneith, J. L., Chichester, UK, Academic Press, 57-109, 1975.

Townsend, A. R., Braswell, B. H., Holland, E. A., and Penner, J. E.: Spatial and temporal patterns in terrestrial carbon storage due to deposition of fossil fuel nitrogen, Ecological Applications, 6, 806-814, 1996.

Trebs, I., Meixner, F. X., Slanina, J., Oties, R. P., Jongejan, P., and Andreae, M. O.: Real-time measurements of ammonia, acidic trace gases and water-soluble inorganic aerosol species at a rural site in the Amazon Basin, Atmos. Chem. Phys., 4, 967-987, 2004,

\section{SRef-ID: 1680-7324/acp/2004-4-967.}

Trebs, I., Metzger, S., Meixner, F. X., Helas, G., Hoffer, A., Rudich, Y., Falkovich, A., Moura, M. A. L., Da Silva, R. J., Artaxo, P., Slanina, J., and Andreae, M. O.: The $\mathrm{NH}_{4}^{+}-\mathrm{NO}_{3}^{-}-\mathrm{Cl}^{-}-\mathrm{SO}_{4}^{2-}-$ $\mathrm{H}_{2} \mathrm{O}$ system and its gas phase precursors at a pasture site in the Amazon Basin: How relevant are mineral cations and soluble organic acids?, J. Geophys. Res.-Atmos., 110, D07303, doi:10.1029/2004JD005478, 2005.

van Hove, L. W. A., Heeres, P., and Bossen, M. E.: The annual variation in stomatal ammonia compensation point of rye grass (Lolium perenne L.) leaves in an intensively managed grassland, Atmos. Environ., 36, 2965-2977, 2002.

Vitousek, P. M., Aber, J. D., Howarth, R. W., Likens, G. E., Matson, P. A., Schindler, D. W., Schlesinger, W. H., and Tilman, D. G.: Human alteration of the global nitrogen cycle: Sources and consequences, Ecological Applications, 7, 737-750, 1997.

Vong, R. J., Vickers, D., and Covert, D. S.: Eddy correlation measurements of aerosol deposition to grass, Tellus Series BChemical and Physical Meteorology, 56, 105-117, 2004.

Wesely, M. L.: Parameterization of Surface Resistances to Gaseous Dry Deposition in Regional-Scale Numerical-Models, Atmos. Environ., 23, 1293-1304, 1989.

Wesely, M. L., Cook, D. R., Hart, R. L., and Speer, R. E.: Measurements and Parameterization of Particulate Sulfur Dry Deposition over Grass, J. Geophys. Res.-Atmos., 90, 2131-2143, 1985.

Wesely, M. L. and Hicks, B. B.: A review of the current status of knowledge on dry deposition, Atmos. Environ., 34, 2261-2282, 2000.

Wexler, A. S. and Seinfeld, J. H.: The Distribution of AmmoniumSalts among a Size and Composition Dispersed Aerosol, Atmos. Environ. Part A-General Topics, 24, 1231-1246, 1990.

Wexler, A. S. and Seinfeld, J. H.: Analysis of Aerosol AmmoniumNitrate - Departures from Equilibrium During SCAQS, Atmos. Environ. Part a-General Topics, 26, 579-591, 1992.

Williams, M. R., Fisher, T. R., and Melack, J. M.: Chemical composition and deposition of rain in the central Amazon, Brazil, Atmos. Environ., 31, 207-217, 1997.

Wyers, G. P., Otjes, R. P., and Slanina, J.: A Continuous-Flow Denuder for the Measurement of Ambient Concentrations and Surface-Exchange Fluxes of Ammonia, Atmos. Environ. Part aGeneral Topics, 27, 2085-2090, 1993. 